DIVISION OF THE HUMANITIES AND SOCIAL SCIENCES

CALIFORNIA INSTITUTE OF TECHNOLOGY

PASADENA, CALIFORNIA 91125

IPO UNDERPRICING IN TWO UNIVERSES: BERLIN, 1882-1892, AND

NEW YORK, 1998-2000

Caroline Fohlin

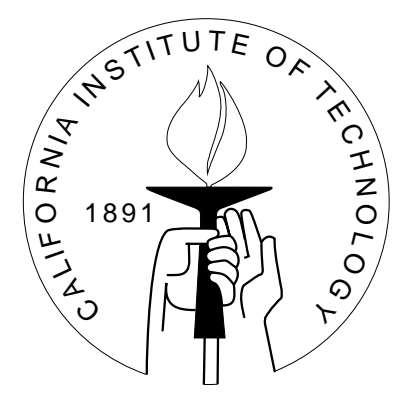

SOCIAL SCIENCE WORKING PAPER 1088

May 2000 


\title{
IPO Underpricing in Two Universes: \\ Berlin, 1882-1892, and New York, 1998-2000
}

\author{
Caroline Fohlin \\ California Institute of Technology
}

Preliminary Draft: May 12, 2000

For presentation at the Conference on Financial Systems and Institutions in the Third Millenium, The Hebrew University of Jerusalem, May 15-18, 2000 


\title{
IPO Underpricing in Two Universes: \\ Berlin, 1882-1892, and New York, 1998-2000
}

\begin{abstract}
Underpricing of new issues relates negatively to underwriter reputation in studies covering the US during the early 1970s until 1997 but positively in one study of IPOs from 1992-4. This paper investigates whether IPO underpricing depends on the organization of the financial system, whether underwriter reputation is a consistent indicator of firm quality and therefore (negatively) of underpricing, and whether this reputation effect also appears in completely different contexts. The study also looks for truncation in the observed returns distributions that may hint at price support activities on the part of underwriters. To answer these questions, the study presents evidence on new issues of stocks and their one-day returns in the Berlin market of 1882-1892 along with parallel data from the New York markets of 1998-2000.

Despite what appear to be major institutional differences between the US and Germany, underpricing and its correlates are remarkably similar in the two cases: median underpricing is nearly the same in the two samples. Strikingly, the link between underwriter reputation and underpricing is positive both in the U.S. of recent years and in Berlin of the 1880s. This finding is in stark contrast with those for the US in the 1970s and 80s. The trade off between prices and rationing faced by underwriters might result in this instability in the reputation-underpricing link. Finally, the observed distributions of first-day returns for both markets display marked skewness toward positive values-a pattern that is consistent with left censoring and quite possibly with underwriter price supports.

These results support a number of conclusions: first, either underwriter reputation is a poor signal of firm quality or firm quality is positively related to underpricing in certain circumstances; second, the largest and most prestigious underwriters may exert market power or at least provide more or better service in return for their higher indirect costs; third, the relationship between underwriter reputation or market share and underpricing clearly varies dramatically over time and across countries; and finally, financial system design-in particular, universal and relationship banking-may have little impact on the performance of new issues markets. Given the German results, one should conclude either that significant information asymmetries exist despite universality and formal relationships in the banking system or that information problems are unnecessary for the emergence of underpricing.
\end{abstract}




\section{IPO Underpricing in Two Universes: \\ Berlin, 1882-1892, and New York, 1998-2000}

\section{Caroline Fohlin*}

Over the past few decades, financial economists have identified consistent positive average returns to new issues of securities in their first day or so of trading. This initial return represents, in many cases, an enormous profit to the primary purchasers of new issues and can be interpreted further as a significant cost to issuers of stocks. Initial returns in the U.S. averaged 11-17 percent from the 1960 s to the early 1990s. ${ }^{1}$ Recent international evidence concludes that the underpricing phenomenon, or "money left on the table," extends to several other countries as well. In Germany, for example, average initial returns have varied between 10 and 22 percent in the post-war period (Huang and Levich, 1998).

Researchers have theorized that positive average initial returns result from the deliberate underpricing of new offers or from speculative bubbles in the early aftermarket trading of new shares. Adherents to asymmetric information theories of underpricing hold that the perceived risk of an offer is a key factor in initial returns: the riskier the new issue, the higher the premium demanded. The reputation of lead underwriters in a new issue, because it is viewed as a good proxy for the quality of an issue, is hypothesized to relate negatively to underpricing. Existing theoretical work is not unanimous on this point, and the research so far on the U.S. reflects this ambiguity: the relationship between underwriter reputation and underpricing is negative in samples covering the early 1970s until 1997 but is positive in one study of IPOs from 1992-4.

This paper offers further insight into these issues by asking, first, whether underpricing depends on the organization of the financial system, second, how persistent the underwriter reputation effect in the U.S. is in recent years, and, third, whether this reputation effect also appears in completely different financial

\footnotetext{
*Division of the Humanities and Social Sciences, California Institute of Technology, mailcode 228-77, Pasadena, CA 91125. fohlin@ @ss.caltech.edu. Thanks are due to Lisa Cowan, William Sharp, and particularly to Anh Pham, who aided significantly in the research. My gratitude goes as well to Peter Bossaerts, John Latting, and Jay Ritter for helpful discussions and advice.
}

${ }^{1}$ See Ibbotson and Jaffe (1975), Ritter (1991), and Ibbotson, Sindelar and Ritter (1994). McDonald and Fisher (1972) find an average market-adjusted return of 28.5 percent in their 1969 sample. 
systems and economic contexts. As a subsidiary issue, the study investigates the possibility of truncation in the observed returns distributions that may hint at price support activities on the part of underwriters. To answer these questions, the study presents evidence on new issues of stocks and their one-day returns in the Berlin market of 1882-1892 along with parallel data from the New York markets of 1998-2000.

Despite what appear to be major institutional differences between the US and Germany, underpricing and its correlates are remarkably similar in the two cases. It will come as no surprise to modern observers that the New York market of the past two years has offered extremely high and increasing average, one-day returns to investors. But the Berlin market of the late nineteenth century left substantial amounts of money 'on the table,' too. In fact, median underpricing is nearly the same in the two samples. Strikingly, the link between underwriter reputation and underpricing is positive both in the U.S. of recent years and in Berlin of the 1880s. This finding is in stark contrast with those for the US in the 1970s and 80s. Finally, the observed distributions of first-day returns for both markets display marked skewness toward positive values-a pattern that is consistent with left censoring and quite possibly with underwriter price supports.

These results support a number of conclusions: first, either underwriter reputation is a poor signal of firm quality or firm quality is positively related to underpricing; second, the largest and most prestigious underwriters may exert market power or at least provide more or better service in return for their higher indirect costs; third, the relationship between underwriter reputation or market share and underpricing clearly varies dramatically over time and across countries; and finally, financial system design-in particular, universal and relationship banking-may have little impact on the performance of new issues markets. The findings here therefore point to an ironic combination of change and persistence in financial market phenomena and emphasize how much there is to learn about the behavior of these markets and the institutions that underpin them.

The next section reviews the existing research on IPO underpricing and underwriter reputation effects; it then discusses the institutional framework of German underwriting in the late nineteenth century and how 
these organizational differences may influence underpricing and its correlates. Section three describes the data used, while section four presents the empirical analysis of the two cases. Section five concludes.

\section{Hypotheses and Past Empirical Findings}

\section{Underpricing}

A number of theoretical models of underpricing have emerged in the past several years; most revolving around information problems. Rock (1986), for example, divides the pool of potential investors into two categories: informed and uninformed. The former can distinguish among IPOs and invest only in issues with a positive expected initial return; the latter are unable to make such a judgement. Fairly pricing IPO's would yield uninformed investors a negative average return, since informed investors would often cause over-subscription and therefore rationing on the high-return issues. Informed investors would leave less profitable issues to the uninformed. In order to attract both uninformed and informed investors, the average IPO must be underpriced. The model implies a positive relationship between the magnitude of underpricing and the risk of an issue. Empirical research so far largely affirms Rock's model (Beatty and Ritter, 1986, Koh and Walter, 1989, and Michaely and Shaw, 1993).

In a related vein, Carter and Manaster (1990) relate the risk of a new issue to underwriter reputation. The prestige of the lead underwriter is seen as a proxy for an issuer's quality; thereby inducing a negative relationship between the underwriter reputation and the amount of underpricing. Carter and Manaster (1990) and Carter, Dark, and Singh (1998) rate underwriters on a ten-point scale, based on their billing in IPO announcements in the Wall Street Journal, and then determine the link between this rating and share price 
performance. These, and a number of other studies, find a statistically significant negative correlation between underpricing and underwriter reputation-results that are arguably consistent with the Rock model. ${ }^{2}$

In contrast, signaling models suggest that, in the presence of asymmetric information, high quality firms underprice more than low quality firms. Using a typical signaling framework, for example, Allen and Faulhaber (1989) and Welch (1989), argue that high-quality firms send a costly signal to the market by underpricing their issues. Low-quality firms cannot afford to use underpricing to falsely signal high quality, because their initial losses from doing so exceed expected long-run returns. Thus, the underpricing signal distinguishes between high and low quality. Chemmanur (1993) suggests, moreover, that underpricing new issues compensates outside investors for their costly information production activities.

Baron's (1982) model characterizes underpricing as a result of the information advantage that underwriters hold over issuers. Setting a low issue price relative to true value increases the probability of placing an issue in its entirety and also reduces the effort needed to sell those shares. Assuming that underwriters' effort in marketing the IPO cannot be successfully monitored by the issuing firm, underwriters will underprice IPOs on average. Despite the theoretical appeal of the model, however, Muscarella and Vetsuypens' (1989) analysis turned up contrary evidence. In particular, the 38 American investment banks that went public between 1970 and 1987-issues that should have been freed from underwriter-issuer information problems-underpriced at rates comparable to those on IPOs of equivalent size.

Also grappling with the issue of asymmetric information, Biais, Bossaerts, and Rochet (1998) provide an optimal mechanism for IPOs. ${ }^{3}$ This approach addresses the moral hazard problems that arise separately in Baron (1982) and Rock (1986): firms have private information about their quality but are relatively uninformed about marketing; while underwriters and institutional investors have superior information about

${ }^{2}$ See Johnson and Miller (1988), Megginson and Weiss (1991), and Lowry and Schwert (2000).

${ }^{3}$ Related work on optimal mechanisms includes Benveniste and Spindt (1989), Benveniste and Wilhelm (1990), and Spatt and Srivastava (1991). 
markets but incomplete or imperfect information about the quality of the issue. An advantage of this analysis is that it deals with the agency problem between the seller and the intermediary and addresses the possibility of cooperation between underwriters and institutional investors. The optimal mechanism yields underpricing as a rent to informed agents. Moreover, the model implies that price is a decreasing function of the quantity allocated to uninformed investors; thereby yielding information revelation by the intermediary and ameliorating the winner's curse problem faced by uninformed investors. The empirical analysis of the French market, particularly useful due to its reporting of rationing, motivates the theoretical results.

\section{Bubbles and Flippers}

Another area of research lays the blame for excess initial returns on investors in the secondary market, rather than on the underwriters of the issues. The first strand in this literature suggests that irrational exuberance creates a bubble-a phenomenon that is consistent both with the large, documented initial returns on IPOs and with their (supposed) longer-run under-performance. Thus, fads or 'hot' markets can create the appearance of underpricing. In a related line of research, DeLong, Shleifer, Summer, and Waldmann (1990) and Lee, Shleifer and Thaler (1991) analyze the impact of so-called 'noise traders.' In the first study, rational investors trade based on rational expectations, but noise traders base decisions on sentiment. These overlyoptimistic traders bid up transaction prices well past intrinsic values. The second study finds that optimistic investing lowers the discount of closed-end funds relative to net asset value, while pessimistic sentiments increase this discount. The latter study also suggests that the issuance of new offerings is related to investors' optimistic sentiment.

A second part of this literature investigates the role of flippers: investors who take part in a new offering with the clear intent of reselling their shares immediately. Flipping activity can flood the market with shares in aftermarket trading, so underwriters must account for this 'false' demand in building their order books 
and in setting the offer price for the new shares. The combination of overselling and flipping can create the observed pattern of high initial returns and lower long-run returns. Such behavior results from rational optimization, rather than irrational exuberance. Krigman, Shaw, and Womack (1999), for example, show that large traders 'flip' their stakes in the 'hottest' issues-those that perform the best in the first day but the worst in subsequent months.

\section{Underwriter Price Support and Over-allotment}

The flipping problem lays part of the responsibility for underpricing back at the feet of underwriters, because it is they who engage in over-allotment and price supports during the early aftermarket trading of the new issues they float. In a sense, then, initial returns are a contrived phenomenon. Ruud (1993) argues that the appearance of positive average initial returns stems from the presence of a partially unobserved negative tail in the returns distribution that arises from the price support of poor performers by their underwriters. The process of underwriter price support tends to cause a truncation in the distribution of initial returns. Ruud (1993) shows that the distribution of returns (on a sample of 463 IPO's in 1982 and 1983) exhibits such left censoring, and that the skewness declines over the four weeks succeeding the offer date. Furthermore, Ruud finds marked evidence that firms with one-day returns of zero migrate to subsequent negative returns. Correcting for the absent observations yields a mean return that is insignificantly different from zero.

Aggarwal (1999) and Ellis, Michaely, and O'Hara (1999) provide substantial direct evidence of overselling and selective price support of new issues, respectively. Fishe (1999) models this behavior theoretically, and shows that underwriters have the incentive to over-sell an IPO, issue shares at a price that is higher than they expect in early aftermarket trading, and then exercise the over-allotment option using lower-priced shares purchased on the market. The results of Krigman, Shaw, and Womack's (1999) study, that flipping is predictable and underpricing intentional, support such an hypothesis. In related work, Asquith, Jones, and 
Kieschnick (1998) argue that initial returns follow a mixed distribution, consistent with a combination of underpricing and price stabilization. In general, the findings on underwriter behavior suggest that theories based on reputation, monitoring, signaling, or even bubbles provide low explanatory power for the overall observed returns distribution.

\section{Underpricing and issuer complacency}

Krigman, Shaw, and Womack's (1999) research indicates that issuers do not consider large underpricing as a reason to switch underwriters for subsequent issues. In fact, those that switch have the lowest underpricing. Loughran and Ritter (1999) take a prospect theory approach to explain this phenomenon. Noting that underpricing is most significant among issues whose offer prices were revised upwards from the filing range (pointed out by Hanley, 1993), these authors argue that founders endure sometimes exorbitant underpricing of their shares, because the original owners are simultaneously confronted with the good news that their wealth is increasing even more than they had expected. This study explains the characteristics of issues that permit the extraction of large rents, taking underpricing as a given. In the modern American case, of course, underpricing benefits underwriters only indirectly, through lowered marketing costs and by necessitating rationing (thereby encouraging investors to overpay on commissions for the chance of being included in hot IPOs). Loughran and Ritter argue that underwriters maximize their total revenue by obscuring some of their charges in these less transparent methods.

This line of research implicitly raises the issue of industrial organization in underwriting. In a perfectly competitive market for underwriting services, underwriters would be unable to impose excess charges through underpricing. The fact that underpricing persists suggests that underwriting is imperfectly competitive and permits the exercise of market power. Such power may emerge if the process of underwriting exhibits network externalities, returns to scale, or product differentiation (say, in the quality of advice). The ability to extract 
rents in this situation does not hinge on information asymmetry and may vary from underwriter to underwriter. An industrial organization framework therefore motivates the postulation of a positive relationship between underwriter reputation or market share and the underpricing they 'charge' on new issues.

\section{The Nineteenth-Century German System}

The recent literature relates primarily to the modern phenomenon of underpricing and focuses largely on the American markets. Since the American financial system differs in design from most others, some understanding of alternative institutions is useful for modifying and then testing existing hypotheses for other contexts. A long line of research compares the organization and operation of different financial systems, with the underlying goal of determining the relative efficiency of those systems.

Much has been made of the apparent differences between the so-called bank-based systems of Germany, Japan, and much of continental Europe and the "market-based" systems of the Anglophone world. Modern financial institutions are rooted in the past, and German universal banking in particular arose in the 1840s and 50s. Strong arguments have emerged about the German banks-in both their historical and modern incarnations-and their innate efficiency. That is, because German banks combine commercial and investment banking within one institution, and because they are supposed to have maintained close, long-term relationships with the firms they financed, these institutions are argued to break down information barriers that marketoriented, arms-length systems cannot overcome. These same banks, it is supposed, took direct equity stakes in a few firms, and indirect proxy stakes in even more. This combination of superior information inflows and economies of scope in the intermediation of information are argued to lower the costs of corporate finance.

Ease of finance arguably encourages the formation of enterprises and the use of outside financing to promote the expansion of those firms. But publicly-traded joint-stock companies could not proliferate until governments removed legal barriers on chartering and financial institutions and markets developed methods 
for issuing and trading shares. In Germany, in particular, these institutional and legal changes arrived in the 1870s, amid a significant push toward industrialization. While there were only 200 joint-stock companies (Aktiengesellschaften) before 1870 , there were over 1,000 shortly thereafter and over 3,000 by 1890 . Nearly all registered share companies gained listing on the Berlin exchange in the first half of the nineteenth century. Though stock market listings grew very rapidly over the century, they lagged behind the growing number of companies. Nonetheless, Berlin listings grew from 612 to 1,005 share issues between 1880 and $1890 .^{4}$

The universal banks performed most of the issuance and placement of new securities in Germany during this period. Flotations could be performed in two ways: by direct subscription of shares (Zeichnungsgründung or successive founding) or by the taking over of shares by a promoter or underwriter and subsequent sale of the shares to the public (Übernahmegründung or simultaneous founding). The latter form prevailed in Germany throughout the pre-World War I era. Moreover, shares frequently traded through the universal banking system and their networks of clients-particularly in the first year of a new corporation's existence, when formal stock exchange listing was legally prohibited. After the imposition of transaction taxes in the early 1880s, and before the closure of tax loopholes in 1900, the large, Berlin-based universal banks economized on tax charges by offsetting their customers' buy and sell orders and taking only the net position to the exchange. Thus, banks maintained close involvement in the setting of prices during the period studied here.

The exchanges employed two sets of brokers for much of the nineteenth century: private brokers and official brokers (vereidigte Maklern). The latter, starting with regulations imposed in 1884, were appointed for life terms and were legally prohibited from trading on their own accounts (but apparently often did so nonetheless) or joining with other brokers. The official brokers were responsible for setting securities prices based on the unified price system. Under this procedure, brokers balanced purchase and sale orders and

${ }^{4}$ Fohlin (2000) provides an overview of the German market and regulations in the nineteenth and early-twentieth centuries. See also Tilly (1995). 
determined, after a round of price announcements and recalculations, the final binding price for all orders placed that day.

Contemporary observers claimed that price setting was not exact or reliable enough and that, in setting the market price, the brokers often followed the wishes of interested bankers, especially when a deal could not be executed on the given day (Wiener, 1905). In an attempt to limit bankers' influence on prices, the stock exchange regulations instituted in 1896 stipulated that prices be officially set by the exchange directors, in the absence of outsiders (i.e., only the commissioner, secretary, brokers, directors, and representatives of other trades prescribed by exchange regulations were permitted to be present). It is unclear how severely the new law constrained bankers' direct influence on pricing, but it seems clear that banks participated indirectly both before and after the law. The period investigated in this paper, 1882-1892, appears to be one in which the banks were very actively involved. ${ }^{5}$

These descriptive accounts suggest that German banker-underwriters of the late nineteenth century should have operated in the long-term interests of firms and clients, and arguably maintained an information advantage relative to underwriters in the United States at the end of the twentieth century. Recalling the theoretical literature on underpricing, one might therefore argue that initial returns to new issues in Germany in the 1880s should be considerably lower than those for American firms in the late 1990s, and that reputation effects, in particular, should be considerably less important. Firms have less need to signal information to investors and risk is reduced in a system in which the same institution provides commercial services to firms throughout their lives, underwrites both their bonds and shares, places the shares directly with investors, takes control (and perhaps sometimes ownership) rights over those equity stakes, and then participates actively in the setting of prices in secondary markets. Moreover, if banks truly gain superior information about firms through long-term relationships that are built up well before the issue of publicly-traded equity shares, and they

\footnotetext{
${ }^{5}$ The study covers a period in which stock prices rose and then fell considerably, thus provoking public outcry and the subsequent investigation by the German government.
} 
take ownership of the full amount of the issue before selling it off to their established network of clients, then information-based incentives to underprice to insure placement should be mitigated.

Of course, underwriters in this scenario may have a direct incentive to underprice issues to earn extra profits off of the difference (which was perfectly legal in Germany during the period of this study). Thus, appealing to the economics of industrial organization, and laying information issues aside, one could plausibly argue that German bankers should be expected to underprice considerably, and those with larger market shares, more extensive networks of clients, and higher prestige could do so all the more.

Finally, given the organization of the markets, and the apparent involvement of banks and bankers in price setting, it seems clear that the German universal banks engaged at least as actively in price supports as do modern American underwriters. Thus, we should observe significant left-censoring in the distribution of initial returns as the universal banks held back shares to maintain share prices at or close to their issue levels.

Hardly any researchers have investigated the link between financial system design and the performance of new issues markets, but a few recent studies have begun to shed light on these questions. The most directly relevant work is that of Ber, Yafeh, and Yosha (2000), who investigate the impact of universality on the underwriting process in Israel in the 1990s. They find that underwriters that are affiliated with a bank issue shares for the strongest (in accounting terms) firms but overprice issues in which associated investment funds participate as purchasers. Fund investors bear the cost of these conflicts of interest.

Huang and Levich (1998) provide international comparisons of underpricing. Though not specifically interested in institutional influences on underpricing, these authors provide evidence that initial returns differ significantly across countries and levels of economic development but vary independently of financial system design. For example, conventional IPOs produced initial returns of 11-12 percent both in the specialized banking systems of Australia and the UK and in the universal system of Germany. These findings are somewhat enlightening, but further research, designed to evaluate the effects of specific institutions, is needed 
to draw firm conclusions about the relative costs and benefits of institutions that combine commercial banking, underwriting, fund management, and brokerage.

In a different vein, Barry, Muscarella, Peavy, and Vetsuypens (1990) study the role of American venture capitalists, whose engagement in intensive monitoring (taking major equity positions, holding their investment beyond the offer date, and serving on clients' boards) is often likened to that of the German universal banks. ${ }^{6}$ In line with information-based hypotheses, these authors find that, among IPOs backed by venture capitalists, underpricing varies negatively with the strength or quality of monitoring. Their findings suggest, however, that the overall magnitude of underpricing is similar for venture and non-venture backed IPOs. This latter result should surprise adherents to information-based theories, since it suggests that concentrated monitoring, in the shape of venture capital backing, does not generally ameliorate the information problems that lead to underpricing.

\section{Data}

The following analysis uses two sets of data to investigate pricing phenomena in the US and Germany. Data on American IPO's were extracted from the web sites www.ipodata.com and www.ipo.com. The web sites provide information for over 1500 IPO filings from 1998-2000, compiled from SEC S1-A forms and other sources. Eliminating REITs, ADRs, and closed-end funds from the sample, as well as those companies that had registered with the SEC but had withdrawn their IPOs or had not yet gone public, left 800 companies (that also had first-day prices). The data include name, ticker symbol, SIC code, filing date, shares offered, offer

${ }^{6}$ Fohlin (1997a, 1998a, 1998b, 1999) argues that formal relationship-banking practices became widespread only at the very end of the nineteenth century in Germany-that is, after the period studied here-and that they were not clearly associated with monitoring or amelioration of information problems once they did develop. Moreover, it appears that the universal banks maintained few long-term stakes in firms they underwrote, but did hold positions in issues that they failed to place in full (Fohlin, 1997b). These findings hint that the German institutional design may also have little impact on underpricing and reputation effects compared with the modern American system. 
date, filing range, offering price, underwriting costs, gross proceeds, and primary underwriter. Post-issue prices for the IPOs are the price of the share at the close of the first day of trading. ${ }^{7}$

Underwriter reputation for the American firms take two forms. The first comes from Carter and Menaster (1990), via Carter, Dark, and Singh (1998). Carter and Menaster rate underwriters by sorting through IPO announcement advertisements and ranking firms by their relative position as lead or counderwriters in the ads. The second reputation variable is the number of issues or market share of the given lead underwriter in the current sample of 1522 IPOs. While the C-M rating relates to the underwriting industry in the early 1990s, the market share variable corresponds directly to the period covered in the analysis (1998 to 2000). Thus, the latter measure may be expected to provide greater explanatory power than the former. The Berlin data for 1882 to 1892 come from the report of the Börsen-Enquette Kommission (Stock Exchange Enquiry Commission) from 1893. This data set contains 335 stock issues with sufficient data (out of 440). The source reports all new issues of shares that became listed in Berlin between 1882 and 1892; some of the issues therefore represent secondary offerings. ${ }^{8}$ In general, if information problems are the key determinant of underpricing, secondary offerings' initial returns may be smaller and relate less closely to bank reputation than those of IPOs. Because of the organization of the German system, though, underpricing and reputation effects may already be mitigated for IPOs, making them appear more similar to SEOs than in the current American context. Thus, the inclusion of SEOs may have little impact in the German case. If there

\footnotetext{
${ }^{7}$ All of the American data were collected and then parsed by computer programs. The price quotes come from Yahoo's historical quote data site (http://chart.yahoo.com/d). The stock price program collected the closing price of the stock on the first trading day following the offer date. In some cases, the quote data was not available on Yahoo. In most cases, it is unclear why the stock prices were missing. In a random sampling of 5 companies that had no price data, four were still listed (the other one had moved to the NYSE from NASDAQ and had changed its ticker symbol). Issues with missing data are much more likely to have been OTC or listed on the AMEX or NASDAQ SmallCap exchanges. The appendix provides detailed comparisons of firms with and without price data.

${ }^{8}$ Further research is required to distinguish among the IPOs and SEOs in this sample. To do so, one must search for dates of incorporation in the reports of such stock market handbooks as Saling's Börsen-Jahrbuch or Handbuch der deutschen Aktiengesellschaften.
} 
is an effect, it should be an underestimation of true IPO initial returns and of the relationship between IPO underpricing and underwriter reputation or frequency.

The reported data include issue size, number of shares issued, price at par, price at issue (expressed in relationship to par value, Kurs), date and Kurs on the first day trading on the Berlin exchange (official listings and unofficial trading; neither of which usually corresponded to the actual issue date), date of filing the required prospectus, and Kurs on December 1, 1890 and December 1, 1892. Since shares usually did not trade on the exchange right away, the initial return is calculated here as the percentage increase or decrease in the share price at the issue date relative to the face value of shares. This measure is not exactly the same as the modern American market return, because the market, in the German case, is created by the universal banks. Still, this measure offers an estimate of the gain to underwriters and opportunity cost to issuers. In practice, the percentage gain on the first day of trading on the Berlin market over the face value of shares is highly correlated with the return at the issue date.

For Germany, reputation ratings are based on a qualitative assessment of the lead underwriters' prestige and type of institution (granting values 0 through 7 for non-financial corporations, low-prestige private banks, low-prestige provincial banks, middling provincial or private banks, top private banks, top provincial banks, the smallest four great banks, and the top five great banks). To augment this variable with a quantitative variable, and for comparability of the results, I also construct lead underwriting frequency and market share variables as in the American case.

Clearly, the disparity in period, location, and institutional structure must be appreciated in comparing the variables and results for the two cases studied here. The inclusion of seasoned offerings in the German sample but not in the American sample, in particular, should be borne in mind, as should the differences in trading of shares and setting of prices. The purpose is to gather a rough impression of the parallels between the two systems and their functioning, rather than to provide a detailed evaluation of systematic differences. 


\section{Results}

Given the apparently vast divide between New York circa 2000 and Berlin circa 1882, it would be surprising if the two markets generated very similar results. A few basic comparisons shed considerable light on the differences and similarities of the two markets. Clearly, the American market for new issues has mushroomed in recent years. We found over 1500 IPO filings in the 26 months from February, 1998 to April, 2000, 800 of which had actually gone public and had the requisite information to determine initial returns. The German financial system, having been pegged as a bank-based system, is usually assumed to support little in the way of securities markets. While German markets of the post-war period (especially until the mid-1990s) may mostly deserve this characterization, the German financial system of the late nineteenth and early twentieth centuries does not. Even in the decade considered here-just 10 years after the loosening of incorporation laws and before the 'hot' markets of the late 1890s and early post-World War I years-the Berlin market listed hundreds of companies and promoted many new issues each year. After deletions for missing price data, the Berlin sample includes 335 new issues.

Despite the differences in activity, market microstructure, and sample selection, both markets yielded large initial returns to investors, underwriters, or their favored clients (Table 1 and Figures 1-4). ${ }^{9}$ In New York of late, the one-day return to IPO's has increased to an average of 67 percent, though the distribution is increasingly skewed by a handful of extreme outliers. Underpricing in Berlin, averaging 31 percent, was lower than very recent American rates, but higher than American rates reported for much of the past 25 years (15-17 percent). The median returns in these two markets are remarkably similar: 27 versus 22.5 percent. Because the Berlin figures include seasoned offers, it is possible that the underpricing for IPOs alone was even higher.

${ }^{9}$ Initial returns definitions appear in the previous section. The American returns are calculated with and without adjustment for market returns on the same day. The market return is the percentage gain in the NASDAQ100 index for the given day. No daily indexes are currently available for the Berlin market in the period studied here. 
Thus, the true gap between the two markets may be even smaller. Also notable, very few Berlin issues earned negative initial returns (the fifth percentile return was zero). This finding might be attributed to a more active selection mechanism by underwriters or to a number of macroeconomic or institutional conditions prevailing in the two markets, countries, or time periods. The final part of this section presents further results on the distributions of returns.

Underwriter frequencies provide a good idea of market shares in the underwriting business. The average head underwriter in Berlin took the lead position in 10 issues during the 10 years, while the average underwriter in New York in the last two years took the position 61 times. The proportion of total issues in which each underwriter took the lead is even more enlightening. Using this measure, the average market share in New York has been 4 percent of late, while in Berlin in the 1880s it was 2.4 percent. Thus, despite the image of a concentrated, bank-dominated system of corporate finance, the German underwriting business appears to have been less concentrated than its recent American counterpart. The fringe of small underwriters is larger in the U.S., though, given that the fifth percentile market share is currently 0.07 percent in the U.S., compared to 0.23 percent in 1880 's Berlin.

The size of new issues and their prices are dramatically different in the two cases. While American issues now average over 150 million dollars, the average Berlin issue equates (roughly) to less than ten million current U.S. dollars. Moreover, median issue value in the US is currently over 600 million, and the fifth percentile is over 8 million. In contrast, the Berlin market floated issues as small as $\$ 180,000$ (M60,000 in 1880s values). There are a number of plausible explanations for the enormous differential in issue size. For example, relative to modern American companies, late nineteenth century firms may have been smaller in general, may have accessed capital markets at earlier ages or smaller sizes, or may have used less share capital (and more debt) to finance operations. The currently-available data do not permit distinction among these or other possibilities. Moreover, it is difficult to determine whether the relatively small size of Berlin issues resulted from the lack of availability of funds to be invested in equity or from a weak demand for equity capital 
on the part of firms. Further research is also needed to determine how the Berlin issues of the 1880s compare to issues in other major markets, such as London, Paris, and New York, in the same era; the issues may not have been small at all, relative to contemporaries.

It is clear that German shares in the 1880s were much more expensive than they are today in the US: averaging nearly $\$ 3,000$ and $\$ 14$ per share, respectively. The natural implication of both the size and price comparisons is the disparity in the number of shares offered. Whereas American firms have been issuing over 9 million shares on average (and as many as 364 million), German firms were issuing 4,000 shares on average and no more than 12,000. Of course, the purchasers of shares differ significantly in the two contexts. Equity investing in Germany during the 1880s (and for many decades following) was the domain of wealthy elites and bankers, so shares did not need to be priced to fit the budget of small, individual investors. Indeed, many issues, or large portions thereof, were placed in the hands of the issuing families or related industrial groups and were traded very little. As a result of many factors, then, German firms could issue fewer shares at higher prices. The contrast with the current American situation-widespread demand for smaller stakes-is obvious.

\section{Correlates of Initial Returns}

The two markets under investigation demonstrate both marked differences and striking similarities in their structure and operation. By estimating initial returns to new issues as a function of several explanatory variables, both for Berlin and for New York, this section helps determine whether the differences or the similarities prevail in the determination of underpricing and the behavior of underwriters. First, though, correlation matrices for New York and Berlin show the raw relationship among several variables of interest (Tables 2 and 3). For both cases, the results turn up large and significant correlations among the various measures of underwriter reputation and market share. Clearly, the reputation of lead underwriters is closely tied to the frequency with which they perform that function. Thus, in the econometric models to follow, 
estimated coefficients on the two types of underwriter variables conflate industrial organization influences (market power and anti-competitive behavior) and information asymmetry problems (returns to monitoring, reputation building, and signaling). While the first factor may increase the extent of underpricing and yield significant, positive coefficients on underwriter reputation, the second factor is argued to have the opposite effect.

These findings also reveal significant raw correlations between underwriter reputation and initial returns. In stark contrast to the American experience of the 1979-91 period, however, the relationship for both Berlin and New York is positive. Underwriter reputation is also significantly positively correlated with offer size in both Germany and the US and with offer price in the US (but not Germany). Clearly, then, the selection process between issuers and underwriters creates some bias in the size of firms ultimately represented by a given category of underwriter. On the other hand, for New York issues, net income scaled by the issue size, is unrelated to underwriter reputation (comparable data are not reported for Berlin issues).

The correlations with the offer date indicate a number of interesting trends. For example, offer prices and the extent of underpricing both increased during the two periods under study. In New York, underwriter reputation is positively correlated with the date of issue, indicating that high prestige underwriters have taken charge of a larger proportion of new issues at least since February of 1998. Despite the increase in prices, offer size is declining in both samples, but more significantly in New York than in Berlin. If offer size measures risk, as is commonly argued, then the decline is size suggests an increase in risk for both of the sample periods. Moreover, in New York, the number of employees (a rough indicator of firm size) has been declining, as has the net income scaled by the size of the issue.

Regression analysis (Tables 4 and 5) confirms the correlation results. Initial returns to new issues are regressed on the various underwriter reputation and frequency variables, logged number of employees (New York only), logged offer size, offering price per share, net income scaled by offer size (New York only), trend, and a set of industry indicator variables (48 for New York and 7 for Berlin). Rather than eliminate extreme 
outliers, I use a variant of the Huber/bi-weight limited-influence estimator in order to down-weight the relevant observations. ${ }^{10}$

As foreshadowed in the correlation matrices, underwriter reputation and frequency are both positively associated with higher initial returns to new issues. In the American case, the results are strongest for the frequency measure, but in the German case, both measures are equally strong (not surprising, given the particularly high correlation between the two measures for Berlin underwriters). For both New York and Berlin, the results are extremely robust to various specification changes. Moreover, the reported results, from the limited-influence estimator, are actually weaker than those for the standard OLS regression (not reported). The latter yields reputation and frequency coefficients that are 50-100 percent higher, depending on other control variables included.

The estimated coefficients, taken literally, indicate that underpricing increases by 20 to 30 basis points for each additional issue promoted by an underwriter in the US, and by $40-65$ basis points for new issues (IPOs and SEOs) in Germany. Using reputation measures instead, the findings suggest that each notch higher on reputation ratings (0-9 for the US and 0-7 for Germany) increases underpricing by approximately 2-4 percentage points. These findings are remarkable for a number of reasons. First, underwriter reputation correlates negatively with initial returns for US samples as late as 1985-1997 (Lowry and Schwert). Thus, the pattern has not just declined in significance or magnitude, but has actually reversed. This finding accords with the analysis of Beatty and Welch (1996) for 1992-4. Lacking an explanation for the apparently sudden switch in the meaning of underwriter reputation, it seems possible that closer investigation of the earlier samples might turn up other sub-periods in which underwriter reputation also relates positively to underpricing. Such analysis would help determine whether the relationship varies from year to year or has undergone a gradual structural shift over the past 10 to 15 years.

\footnotetext{
${ }^{10}$ The limited-influence estimator uses Huber-White iterations followed by Bi-weight iterations. The analysis was implemented in Stata6, whose reference manuals provide in-depth description of the procedure.
} 
The Berlin results indicate that the recent findings for New York represent an ongoing, not an anomalous, phenomenon. The fact that the German case covers a full decade, and precedes the American case by over 100 years, makes it all the more difficult to argue that the results for New York represent a one-time change in a parameter value. Arguably, the German results also further undermine the ideas of signaling, monitoring, and reputation building. These theories, laid out previously, suggest that underwriter reputation should have less influence in a universal system; and yet the results here-to the extent that we can draw direct comparisons-indicate the opposite. If underwriter reputation proxies for market power, however, and if that power is more easily exercised in current-day New York or late-nineteenth-century Berlin, then the positive relationship with underpricing should be expected. Of course, one might also argue that high reputation underwriters offer more or better services, and that the extra underpricing therefore simply represents part of their remuneration. Such an argument carries more weight in the German context, in which underwriters stood to gain directly from underpricing and issuers benefitted significantly from the more liquid markets for placements that the larger, more prestigious underwriters provided. Under either interpretation of the positive relationship, the results argue for greater attention to the industrial organization of underwriting.

The analysis also picks up another important effect: price. In both the American and German cases, the offering share price of the new issue is very strongly positively related to initial returns. This result suggests that prices contain valuable news about the issue. These findings support Biais, Bossaerts, and Rochet (1998), in which the authors argue that, in an optimal IPO mechanism, the price of a new issue reflects the information of informed underwriters and therefore corresponds positively to its expected market value. ${ }^{11}$ The effect appears particularly strong for the New York sample, but most of the difference in coefficient estimates stems from the divergence in offering prices in the two markets. After accounting for the much higher prices of Berlin shares, the share price effects are very similar: a ten percent increase in offer price from the

\footnotetext{
${ }^{11}$ In related work, Bossaerts and Hillion (2000) find that the widely-cited poor performance of IPO's over the medium term (3-5 years) disappears with proper accounting for the original price level and with a longer time span (10 years).
} 
mean, all else equal, is associated with a gain in initial returns of approximately three percentage points in both cases. Certain specifications yield larger coefficients on offer prices for New York and smaller estimates for Berlin, so it does appear that the price effect is stronger for the former than for the latter. This result might be expected, since offering prices varied much less in Berlin in the 1880s than they do in New York today. The Berlin market (and its New York contemporary) began to impose price minimums on listed stocks, and about half of all issues carried share prices of M 1,000.

Though not reported, all of the models include industry indicator variables-48 in the US case, and 7 in the German case. In the US, these variables indicate highly significant sectoral effects on underpricing, when compared to a base category, such as agriculture, that earned returns near the median of the current sample. Not surprisingly, the highest initial returns go to internet software and service providers (comprising over 300 of the 800 firms with return data), telecommunications issues, and other computer technology firms. A couple of industries with only one firm in the current sample had extreme returns: healthcare products (positive) and information technology (negative).

The sectoral influences are less pronounced in the German case. The mining industry, because it was the most prevalent and had returns around the median, is the omitted category for Germany. In comparison with this sector, financial institutions clearly produced smaller initial returns, and textiles returned slightly higher. The banking sector result is particularly interesting, since it suggests that banks were less subject to underpricing than were most other firms. Yet financial institution issues still made significant positive initial returns. Since even large, universal bank-underwriters typically issued shares through a different bank, the persistence of underpricing in this context may be less surprising. The relatively weaker sectoral effects overall may also be explained easily. Relative to the modern American experience, German returns from the late nineteenth century are likely more evenly distributed across sectors, because emerging technology is less concentrated in specific industries during industrialization. Despite these differences, in both cases, the 
inclusion of industry controls lessens the estimated influence of underwriter variables on underpricing. Thus, analysis that fails to control for industry effects may mis-measure reputation effects.

Finally, for both Berlin and New York, the results indicate strong trends toward higher initial returns (Figures 1-4 as well). The trend appears to be particularly strong, especially in light of the short time period, in the American case. For the American case, more time is obviously required to determine the longer-term persistence of the current trend and the long-term performance of the new issues in the current sample. In the German case, additional data can and should be collected to measure the long-run performance of new issues in general, and specific issues in particular.

Because the reported regressions use a limited-influence estimator, R-squared statistics are not calculated. For standard OLS regressions using the same model specifications, the R-squared statistics range between 15 and 25 percent. While this explanatory power is low in absolute terms, it is at least as high as, if not higher than, that apparent in other recent studies of IPO returns. Nonetheless, the low R-squared statistics in the literature generally indicate that the factors thus far identified, though significant individually, together explain only a small portion of the observed variation in initial returns to new issues. Hypotheses about the impact of underwriter price supports, flipping, and over-allotment provisions may provide more pieces to the puzzle.

\section{Underwriter Price Support}

Underwriter price support is cannot be directly determined in the current samples, but insights may be gleaned from the distribution of initial returns to new issues. In both cases studied here, the data on first-day returns demonstrate significant left censoring (figures 5-7). All figures use a kernel density estimator to give a 
smoother representation of the distribution of returns than is provided by the histogram. ${ }^{12}$ In both Berlin and New York, the truncation is very apparent. For the US, the mean is nearly two and half times the median, and the skewness and kurtosis of the distribution are 2.6 and 12.1, respectively. More than a third of the observations lie between zero and 27 percent (the median), and twenty percent were zero or negative. Only five percent of returns are exactly zero, but twice as many as that fall between negative and positive two percent.

In the German case, the mean is not quite one and a half times the median, but the skewness and kurtosis, respectively, are 2.7 and 14.3 . Nearly 47 percent of initial returns in this sample lie between zero and the median (22.5 percent). At the same time, 12.5 percent of issues returned zero or less-two-thirds of which were exactly zero. Viewing the two densities in tandem (Figure 7) reveals the fatter tails, on both sides of the distribution, for New York compared to Berlin. The difference seems to suggest that Berlin underwriters provided even more price support intervention than do current American underwriters. Such a result would not be surprising, given the apparent involvement of universal banks in the placement and early trading of shares, the more direct interest of the banks in the success of issues, and the stricter regulations governing the listing of shares in the Berlin market, compared to modern-day New York.

\section{Conclusions}

This paper offers a unique comparative view of new issue performance in two completely different contexts: Berlin in the 1880s and New York from 1998-2000. Instead of providing a stable baseline against which other experiences may be measured, the New York market appears itself to have changed in recent years. In particular, the long-standing negative relationship between underwriter reputation and underpricing is reversed in the American market of 1998-2000 (confirming a similar finding for 1992-4). The results indicate further

\footnotetext{
${ }^{12}$ The density estimations use an Epanechnikov kernel with a window width that is based on the minimum mean integrated square error assuming a Gaussian distribution and kernel.
} 
that this positive relationship is an enduring or at least periodic one, as it already existed in the Berlin market over a hundred years earlier. The positive connection between underwriter reputation and underpricing may undermine recent interpretations of American IPO underpricing as an automatic response to or result of private information about issuers. To maintain these arguments, one must either believe that high-prestige underwriters suddenly switched to underwriting high-risk stocks in the 1990s or conclude that underwriter reputation is simply an inaccurate signal of issuer risk (producing spurious correlations that are positive and negative, depending on other circumstances). The trade off between prices and rationing faced by underwriters, as modeled in Biais, Bossaerts, and Rochet (1998), for example, might result in this instability in the reputationunderpricing link. One must also reconcile underpricing with a universal, relationship financial system in which information asymmetries are supposed to be ameliorated. Given the German results, one should conclude either that significant information asymmetries exist despite universality and formal relationships or that information problems are unnecessary for the emergence of underpricing.

The close relationship between underwriter reputation and their market shares suggests that underpricing represents one component of the cost of floating a new issue-whether reflective of the value added by high prestige underwriters or the rents extracted by those with larger market shares. This argument makes sense if the ability to extract rents varies over time, so that having high market share is necessary but not sufficient for extreme underpricing. In this case, the underwriter reputation or market share variable would be positive only when circumstances permit exercise of market power. The German example bolsters this explanation, as the largest Berlin banks clearly gained the largest market share in underwriting in Berlin, maintained the most extensive networks of clients with which to place shares (thus providing the capacity for rationing), and therefore were the best candidates for exercising market power.

The analysis also reveals a positive trend and important sectoral effects in underpricing. Interestingly, financial issues in Germany still produce large initial returns, but they are smaller than any other sector. The 
findings also suggest, in support of recent theoretical work on share rationing mechanisms, that the price of shares contains important positive information about the quality or expected returns of new issues.

Finally, the distributions of returns in both New York and Berlin demonstrate significant skewness, consistent with marked left censoring. This finding lends further credence to the idea that underwriter price supports limit the downside on new issues in their first days of trading. The censoring of returns is particularly strong in the German case, in line with the widely-cited involvement of the universal bank-underwriters in the operation of the market for new issues in the nineteenth century. This finding is also consistent with the fact that German universal banks profited directly from underpricing and from rationing shares to support prices.

The results here indicate that much remains to be learned about the pricing and performance of new issues of equity and about the impact of financial system design on the operation of securities markets. The agenda should include a deeper investigation of the industrial organization and market power of underwriters and their ability to extract returns through this "money left on the table" as well as a longer-term investigation of the performance of both samples analyzed here. The findings also suggest that history holds important insights for understanding modern institutions and markets. The German case of the late nineteenth and early twentieth centuries, in which large, universal banks operated alongside active securities markets, may prove to be of particular interest in light of recent developments in the organization of financial systems worldwide. 


\section{References}

Allen, F., and G. Faulhaber, 1989, Signaling by underpricing in the IPO market, Journal of Financial Economics, Volume 23, No. 2, 303-325.

Asquith, Daniel, and Jonathan D. Jones, and Robert Kieschnick, 1998, Evidence on price stabilization and underpricing in early IPO returns, The Journal of Finance, Volume 28, No. 5, 1759-1773.

Barry, C., C. Muscarella, J. Peavy, M. Vetsuypens, 1990, The role of venture capital in the creation of public companies: evidence from the going public process, Journal of Financial Economics, Volume 27, No. 2, 447- 472.

Beatty, Randolph P., and Ritter, Jay R., 1986, Investment banking, reputation, and the underpricing of initial public offerings, Journal of Financial Economics, Volume 15, No. 1 / 2, 213-232.

Beatty, Randolph P. and Ivo Welch, 1996, Issuer expenses and legal liability in initial public offerings, The Journal of Law \& Economics, Volume 39 (2), 545-602.

Benveniste and Spindt, 1989, How investment bankers determine the offer price and allocation of new issues, Journal of Financial Economics, 343-362.

Benveniste, L. and Wilhelm, W., 1990, A comparative analysis of IPO proceeds under alternative regulatory environments, Journal of Financial Economics, 28, 173-207.

Ber, Hedva, Yishay Yafeh, and Oved Yosha, 2000, Conflict of interest in universal banking: bank lending, stock underwriting, and fund management, working paper, Tel Aviv University.

Biais, Bruno, Peter Bossaerts, and Jean-Charles Rochet, 1998, An optimal IPO mechanism, forthcoming, Review of Economic Studies.

Bossaerts, Peter, and Pierre Hillion, 2000, IPO post-issue markets: questionable predilections but diligent learners?, forthcoming in Review of Economics and Statistics.

Carter, R., F. Dark, and A. Singh, 1998, Underwriter reputation, initial returns, and the long-run performance of IPO stocks, Journal of Finance, Volume LIII, No.1, 285312.

Carter, R. and S. Manaster, 1990, Initial public offerings and underwriter reputation, Journal of Finance, Volume XLV, NO. 4, 10451068.

Chemmanur, T., 1993, The pricing of initial public offerings: a dynamic model with information production, Journal of Finance, Volume XLVIII, No. 1, March, 285304.

De Long, J., A. Schleifer, L. Summers, R. Waldmann, 1990, Noise trander risk in financial markets,: Journal of Political Economy.

Fishe, R. P.H., 1999, How stock flippers affect IPO pricing and stabilization, University of Miami and USSEC, working paper, SSRN Electronic Paper Collection. 
Fohlin, Caroline, 1997a, Universal banking networks in pre-war Germany: new evidence from company financial data, Research in Economics, 51, 201-225.

Fohlin, Caroline, 1997b, Bank securities holdings and industrial finance before world war I: Britain and Germany compared, Business and Economic History, 26, 463-475.

Fohlin, Caroline, 1998a, The rise of interlocking directorates in imperial Germany, Economic History Review, LII, 2, 307-333.

Fohlin, Caroline, 1998b, Relationship banking, liquidity, and investment in the German industrialization, Journal of Finance, 53, 1737-1758.

Fohlin, Caroline, 1999,Universal banking in pre-world war I Germany: model or myth? Explorations in Economic History, 36, 305-343.

Fohlin, Caroline, 2000, Company law, stock market regulation, and the development of the German banking system, Social Science Working Paper 1065R, California Institute of Technology.

Hanley, K. W., 1993, Underpricing of initial public offerings and the partial adjustment phenomenon, Journal of Financial Economics 34, 231-250.

Huang, Q. and R. Levich, 1998, Underpricing of new equity offerings by privatized firms: an international test, Hofstra and New York Universities, SSRN Electronic Paper Collection.

Ibbotson, R., J. Sindelar and J. Ritter, 1994, The market's problems with the pricing of initial public offerings, Journal of Applied Corporate Finance, Volume 7, No. 1, Spring, 66-74.

Koh, F. and T. Walter, 1989, A direct test of Rock's model of the pricing of unseasoned issues, Journal of Financial Economics, Volume 23, No. 2, 251-272.

Krigman, L. W. Shaw, and K. Womack, 1999, The persistence of IPO mispricing and the predictive power of flipping, Journal of Finance, Volume 54, 1015-1044.

Loughran, Tim and Jay R. Ritter, 1999, Why don't issuers get upset about leaving money on the table in IPOs? working paper, University of Notre Dame and University of Florida.

Lowry, M. and G. W. Schwert, 2000, IPO market cycles: an exploratory investigation, University of Rochester and University of Southern California, working paper, SSRN Electronic Paper Collection.

Megginson, W., and K. Weiss, 1991, Venture capitalist certification in initial public offerings, Journal of Financial Economics, Volume 46, No. 3, 879-904.

Michaely, R. and W. Shaw, 1994, The pricing of initial public offerings: tests of adverse - selection and signaling theories, Review of Financial Studies, Summer Volume 7, No. 2, 279-319.

Muscarella, C. and M. Vetsuypens, 1989, A simple test of Baron's model of IPO underpricing, Journal of Financial Economics, 24, 125-135. 
Rock, K., 1986, Why new issues are underpriced, Journal of Financial Economics, 15, 187-212.

Spatt, C. and Srivastava, S., 1991, Preplay communication, participation restrictions, and efficiency in initial public offerings, The Review of Financial Studies, 4 (4), 709-726.

Tilly, Richard. The Berlin securities exchange in national context: actors, rules and reforms to 1914, working paper, University of Münster, Germany, 1995.

Welch, I., 1989, Seasoned offerings, imitation costs, and the underpricing of initial public offerings, Journal of Finance, Volume XLVI, No. 2, 421-449.

Wiener, F., 1905, Die Börse, Ph.D. dissertation, Berlin. 
Table 1. Descriptive Statistics

\begin{tabular}{|c|c|c|c|c|}
\hline \multirow{2}{*}{ Variable } & \multicolumn{2}{|l|}{ New York, 1998-2000 } & \multicolumn{2}{|l|}{ Berlin, 1882-1892 } \\
\hline & $\begin{array}{r}\text { mean } \\
\text { standard deviation } \\
\end{array}$ & $\begin{array}{r}5^{\text {th }}, 50^{\text {th }} \text {, and } 95^{\text {th }} \\
\text { percentiles }\end{array}$ & $\begin{array}{r}\text { mean } \\
\text { standard deviation } \\
\end{array}$ & $\begin{array}{r}5^{\text {th }}, 50^{\text {th }} \text {, and } 95^{\text {th }} \\
\text { percentiles }\end{array}$ \\
\hline \multirow{3}{*}{$\begin{array}{l}\text { Raw one-day return on } \\
\text { new issues }\end{array}$} & 66.64 & -17.49 & 31.11 & 0.00 \\
\hline & 104.17 & 27.07 & 40.58 & 22.50 \\
\hline & & 274.55 & & 104.00 \\
\hline \multirow{3}{*}{$\begin{array}{l}\text { Market-adjusted one- } \\
\text { day returns }\end{array}$} & 67.17 & -17.52 & & \\
\hline & 104.69 & 27.70 & & \\
\hline & & 277.99 & & \\
\hline \multirow{3}{*}{ Underwriter frequency } & 61.44 & 1.00 & 10.50 & 1.00 \\
\hline & 50.56 & 53.00 & 9.70 & 8.00 \\
\hline & & 143.00 & & 34.00 \\
\hline \multirow{3}{*}{$\begin{array}{l}\text { Underwriter } \\
\text { share }(\%)\end{array}$} & 4.04 & 0.07 & 2.38 & 0.23 \\
\hline & 3.32 & 3.48 & 2.20 & 1.81 \\
\hline & & 9.40 & & 7.71 \\
\hline \multirow{3}{*}{$\begin{array}{l}\text { Size of issue } \\
\text { (millions current dollars } \\
\text { or marks) }\end{array}$} & 157.00 & 8.40 & 3.05 & 0.24 \\
\hline & 629.00 & 639.00 & 6.81 & 1.36 \\
\hline & & 400.00 & & 10.00 \\
\hline \multirow{3}{*}{$\begin{array}{l}\text { Price of shares at offer } \\
\text { (current dollars or } \\
\text { marks) }\end{array}$} & 14.56 & 6.00 & 965.33 & 300.00 \\
\hline & 8.20 & 14.00 & 368.38 & 1000.00 \\
\hline & & 24.79 & & 1500.00 \\
\hline \multirow{3}{*}{$\begin{array}{l}\text { Number of shares } \\
\text { offered (thousands) }\end{array}$} & $9,295.73$ & $1,000.00$ & 4.75 & 0.20 \\
\hline & $23,900.00$ & $4,437.81$ & 17.32 & 1.50 \\
\hline & & $27,200.00$ & & 12.00 \\
\hline
\end{tabular}

Note: Standard deviations are in italics. Raw one-day return is the percentage change in price on the first day of trading of the new issue. Market -adjusted return subtracts the NASDAQ100 return from the raw return for the same day $(86 \%$ of the American IPO's were listed on NASDAQ). Underwriter frequency is the number of times an underwriter took the lead position, while underwriter share divides that number by the total number of new issues. Size of issue is the value, in current dollars or marks, of the new issue. Offering price is the price at which the new shares are sold at issue. Multiply mark values in 1887 by 3 to approximate dollars in 2000 . 
Table 2. Correlation Coefficients for American IPO's

\begin{tabular}{|c|c|c|c|c|c|c|c|c|c|c|c|}
\hline & $\mathrm{CM}$ & MW & $\begin{array}{l}\text { Under- } \\
\text { writer } \\
\text { freq. } 1\end{array}$ & $\begin{array}{l}\text { Under- } \\
\text { writer } \\
\text { freq. } 2\end{array}$ & $\begin{array}{l}\text { Raw } \\
1^{\text {st }} \text { day } \\
\text { return }\end{array}$ & $\begin{array}{l}\text { Mkt.- } \\
\text { adj. } 1^{\text {st }} \\
\text { day ret. } \\
\text { (mar0) }\end{array}$ & $\begin{array}{r}\mathrm{Ln} \\
(\mathrm{mar} 0)\end{array}$ & $\begin{array}{c}\mathrm{Ln} \\
\text { (empl.) }\end{array}$ & $\begin{array}{r}\text { Ln } \\
\text { (offer } \\
\text { amt.) }\end{array}$ & $\begin{array}{l}\text { Offer } \\
\text { Price }\end{array}$ & $\begin{array}{r}\text { Net } \\
\text { inc./ } \\
\text { offer } \\
\text { amount }\end{array}$ \\
\hline $\begin{array}{l}\text { MW } \\
\text { reputation }\end{array}$ & $\begin{array}{r}0.39 \\
0.00 \\
1196\end{array}$ & & & & & & & & & & \\
\hline $\begin{array}{l}\text { Under- } \\
\text { writer } \\
\text { freq. } 1\end{array}$ & $\begin{array}{r}0.55 \\
0.00 \\
666\end{array}$ & $\begin{array}{r}0.43 \\
0.00 \\
666\end{array}$ & & & & & & & & & \\
\hline $\begin{array}{l}\text { Under- } \\
\text { writer } \\
\text { freq. } 2\end{array}$ & $\begin{array}{r}0.56 \\
0.00 \\
1196\end{array}$ & $\begin{array}{r}0.43 \\
0.00 \\
1196\end{array}$ & $\begin{array}{r}0.99 \\
0.00 \\
802\end{array}$ & & & & & & & & \\
\hline $\begin{array}{l}\text { Raw } 1^{\text {st }} \text { day } \\
\text { return }\end{array}$ & $\begin{array}{r}0.15 \\
0.00 \\
664\end{array}$ & $\begin{array}{r}0.07 \\
0.07 \\
664\end{array}$ & $\begin{array}{r}0.27 \\
0.00 \\
800\end{array}$ & $\begin{array}{r}0.27 \\
0.00 \\
800\end{array}$ & & & & & & & \\
\hline $\begin{array}{l}\text { Market-adj. } \\
1^{\text {st }} \text { day ret. }\end{array}$ & $\begin{array}{r}0.16 \\
0.00 \\
653\end{array}$ & $\begin{array}{r}0.07 \\
0.07 \\
653\end{array}$ & $\begin{array}{r}0.27 \\
0.00 \\
786\end{array}$ & $\begin{array}{r}0.27 \\
0.00 \\
786\end{array}$ & $\begin{array}{r}1.00 \\
0.00 \\
786\end{array}$ & & & & & & \\
\hline $\begin{array}{l}\operatorname{Ln}(\text { market } \\
\text { adj. } 1^{\text {st }} \text { day } \\
\text { ret. })\end{array}$ & $\begin{array}{r}0.17 \\
0.00 \\
533\end{array}$ & $\begin{array}{r}0.03 \\
0.44 \\
533\end{array}$ & $\begin{array}{r}0.27 \\
0.00 \\
630\end{array}$ & $\begin{array}{r}0.27 \\
0.00 \\
630\end{array}$ & $\begin{array}{r}0.74 \\
0.00 \\
630\end{array}$ & $\begin{array}{r}0.74 \\
0.00 \\
630\end{array}$ & & & & & \\
\hline $\begin{array}{l}\text { Ln (number } \\
\text { of company } \\
\text { employees) }\end{array}$ & $\begin{array}{r}0.23 \\
0.00 \\
1033\end{array}$ & $\begin{array}{r}0.20 \\
0.00 \\
1033\end{array}$ & $\begin{array}{r}0.30 \\
0.00 \\
722\end{array}$ & $\begin{array}{r}0.33 \\
0.00 \\
1326\end{array}$ & $\begin{array}{r}-0.11 \\
0.00 \\
721\end{array}$ & $\begin{array}{r}-0.11 \\
0.00 \\
713\end{array}$ & $\begin{array}{r}-0.13 \\
0.00 \\
574\end{array}$ & & & & \\
\hline $\begin{array}{l}\text { Ln (offer } \\
\text { amount) }\end{array}$ & $\begin{array}{r}0.43 \\
0.00 \\
1196\end{array}$ & $\begin{array}{r}0.31 \\
0.00 \\
1196\end{array}$ & $\begin{array}{r}0.51 \\
0.00 \\
802\end{array}$ & $\begin{array}{r}0.54 \\
0.00 \\
1522\end{array}$ & $\begin{array}{r}0.10 \\
0.00 \\
800\end{array}$ & $\begin{array}{l}0.11 \\
0.00 \\
786\end{array}$ & $\begin{array}{r}0.11 \\
0.01 \\
630\end{array}$ & $\begin{array}{r}0.53 \\
0.00 \\
1326\end{array}$ & & & \\
\hline Offer price & $\begin{array}{r}0.26 \\
0.00 \\
779\end{array}$ & $\begin{array}{r}0.16 \\
0.00 \\
779\end{array}$ & $\begin{array}{r}0.38 \\
0.00 \\
800\end{array}$ & $\begin{array}{r}0.37 \\
0.00 \\
1018\end{array}$ & $\begin{array}{r}0.24 \\
0.00 \\
800\end{array}$ & $\begin{array}{r}0.25 \\
0.00 \\
786\end{array}$ & $\begin{array}{r}0.24 \\
0.00 \\
630\end{array}$ & $\begin{array}{r}0.34 \\
0.00 \\
898\end{array}$ & $\begin{array}{r}0.58 \\
0.00 \\
1018\end{array}$ & & \\
\hline $\begin{array}{l}\text { Net inc./ } \\
\text { offer } \\
\text { amount }\end{array}$ & $\begin{array}{r}-0.02 \\
0.50 \\
1155\end{array}$ & $\begin{array}{r}0.01 \\
0.67 \\
1155\end{array}$ & $\begin{array}{r}-0.07 \\
0.04 \\
772\end{array}$ & $\begin{array}{r}-0.02 \\
0.42 \\
1456\end{array}$ & $\begin{array}{r}-0.09 \\
0.02 \\
770\end{array}$ & $\begin{array}{r}-0.08 \\
0.02 \\
756\end{array}$ & $\begin{array}{r}-0.20 \\
0.00 \\
610\end{array}$ & $\begin{array}{r}-0.03 \\
0.26 \\
1280\end{array}$ & $\begin{array}{r}0.06 \\
0.03 \\
1456\end{array}$ & $\begin{array}{r}0.04 \\
0.23 \\
959\end{array}$ & \\
\hline Date of IPO & $\begin{array}{r}0.13 \\
0.00 \\
867 \\
\end{array}$ & $\begin{array}{r}0.05 \\
0.14 \\
867 \\
\end{array}$ & $\begin{array}{r}0.23 \\
0.00 \\
799 \\
\end{array}$ & $\begin{array}{r}0.22 \\
0.00 \\
1067\end{array}$ & $\begin{array}{r}0.26 \\
0.00 \\
799 \\
\end{array}$ & $\begin{array}{r}0.27 \\
0.00 \\
786 \\
\end{array}$ & $\begin{array}{r}0.37 \\
0.00 \\
630 \\
\end{array}$ & $\begin{array}{r}-0.05 \\
0.12 \\
943 \\
\end{array}$ & $\begin{array}{r}0.21 \\
0.00 \\
1067 \\
\end{array}$ & $\begin{array}{r}0.20 \\
0.00 \\
942 \\
\end{array}$ & $\begin{array}{r}-0.08 \\
0.01 \\
1023 \\
\end{array}$ \\
\hline
\end{tabular}

Note: for each variable, the top row presents the pair-wise correlation coefficient, the middle row gives the significance level (p-value) of the correlation, and the third row displays the number of observations used. CM and MW are the CarterMenaster and Megginson-Weiss reputation variables, respectively. Underwriter frequency is the number of times an underwriter took the lead position. $\mathrm{Ln}$ (employees) is the number of employees in the IPO company at the time of filing. $\mathrm{Ln}$ (offer size) is the value, in current dollars, of the IPO. Offering price is the price at which the IPO shares are sold. Net income/offer amount, is the net income, as stated in the issuing company's financial statement of the last fiscal year, normalized by the value of the issue. 
Table 3. Correlation Coefficients for German IPO's

\begin{tabular}{|c|c|c|c|c|c|c|}
\hline & $\begin{array}{r}\text { Under-writer } \\
\text { frequency }\end{array}$ & $\begin{array}{r}\text { Underwriter } \\
\text { reputation }\end{array}$ & $\begin{array}{r}\text { Underwriter } \\
\text { share }(\%)\end{array}$ & $\begin{array}{r}\text { Raw } 1^{\text {st }} \text { day } \\
\text { return }\end{array}$ & Offer size & Offer Price \\
\hline $\begin{array}{l}\text { Under-writer } \\
\text { reputation }\end{array}$ & $\begin{array}{r}0.76 \\
0.00 \\
441\end{array}$ & & & & & \\
\hline $\begin{array}{l}\text { Underwriter } \\
\text { share }(\%)\end{array}$ & $\begin{array}{r}1.00 \\
0.00 \\
441\end{array}$ & $\begin{array}{r}0.76 \\
0.00 \\
441\end{array}$ & & & & \\
\hline Raw $1^{\text {st }}$ day return & $\begin{array}{r}0.18 \\
0.00 \\
333\end{array}$ & $\begin{array}{r}0.15 \\
0.01 \\
333\end{array}$ & $\begin{array}{r}0.18 \\
0.00 \\
333\end{array}$ & & & \\
\hline Ln (offer amount) & $\begin{array}{r}0.19 \\
0.00 \\
439\end{array}$ & $\begin{array}{r}0.23 \\
0.00 \\
439\end{array}$ & $\begin{array}{r}0.19 \\
0.00 \\
439\end{array}$ & $\begin{array}{r}0.01 \\
0.89 \\
335\end{array}$ & & \\
\hline Offer price & $\begin{array}{r}0.06 \\
0.24 \\
434\end{array}$ & $\begin{array}{r}0.07 \\
0.15 \\
434\end{array}$ & $\begin{array}{r}0.06 \\
0.24 \\
434\end{array}$ & $\begin{array}{r}0.13 \\
0.02 \\
333\end{array}$ & $\begin{array}{r}-0.05 \\
0.34 \\
437\end{array}$ & \\
\hline Date of IPO & $\begin{array}{r}0.02 \\
0.64 \\
441\end{array}$ & $\begin{array}{r}0.06 \\
0.22 \\
441\end{array}$ & $\begin{array}{r}0.02 \\
0.64 \\
441\end{array}$ & $\begin{array}{r}0.10 \\
0.07 \\
335\end{array}$ & $\begin{array}{r}-0.05 \\
0.30 \\
441\end{array}$ & $\begin{array}{r}0.33 \\
0.00 \\
436\end{array}$ \\
\hline
\end{tabular}

Note: for each variable, the top row presents the pair-wise correlation coefficient, the middle row gives the significance level (p-value) of the correlation, and the third row displays the number of observations used. CM and MW are the CarterMenaster and Megginson-Weiss reputation variables, respectively. Underwriter frequency is the number of times an underwriter took the lead position. Ln(employees) is the number of employees in the IPO company at the time of filing. $\mathrm{Ln}$ (offer size) is the value, in current dollars, of the IPO. Offering price is the price at which the IPO shares are sold. Net income/offer amount, is the net income, as stated in the issuing company's financial statement of the last fiscal year, normalized by the value of the issue. 
Table 4. Factors Associated with American IPO Underpricing, 1998-2000

\begin{tabular}{|c|c|c|c|c|c|c|}
\hline & 1 & 2 & 3 & 4 & 5 & 6 \\
\hline $\begin{array}{l}\text { Underwriter } \\
\text { frequency }\end{array}$ & $\begin{array}{l}0.28 \\
0.00\end{array}$ & $\begin{array}{l}0.27 \\
0.00\end{array}$ & $\begin{array}{l}0.21 \\
0.00\end{array}$ & $\begin{array}{l}0.23 \\
0.00\end{array}$ & & \\
\hline $\begin{array}{l}\text { Underwriter } \\
\text { reputation }\end{array}$ & & & & & $\begin{array}{l}4.41 \\
0.06\end{array}$ & $\begin{array}{l}1.97 \\
0.43\end{array}$ \\
\hline Ln (employees) & $\begin{array}{l}-5.51 \\
0.00\end{array}$ & $\begin{array}{l}-6.09 \\
0.01\end{array}$ & $\begin{array}{l}-8.08 \\
0.00\end{array}$ & $\begin{array}{l}-6.82 \\
0.00\end{array}$ & $\begin{array}{l}-4.20 \\
0.07\end{array}$ & $\begin{array}{l}-6.55 \\
0.02\end{array}$ \\
\hline Ln (offer size) & & $\begin{array}{l}1.54 \\
0.61\end{array}$ & & $\begin{array}{l}-8.15 \\
0.02\end{array}$ & & $\begin{array}{l}-7.91 \\
0.07\end{array}$ \\
\hline $\begin{array}{l}\text { Offering price } \\
\text { per share }\end{array}$ & & & $\begin{array}{l}2.07 \\
0.00\end{array}$ & $\begin{array}{l}3.56 \\
0.00\end{array}$ & & $\begin{array}{l}4.26 \\
0.00\end{array}$ \\
\hline $\begin{array}{l}\text { Net income/offer } \\
\text { amount }\end{array}$ & & & & $\begin{array}{l}-8.86 \\
0.44\end{array}$ & & $\begin{array}{l}-9.71 \\
0.51\end{array}$ \\
\hline Trend & $\begin{array}{l}0.05 \\
0.00\end{array}$ & $\begin{array}{l}0.05 \\
0.00\end{array}$ & $\begin{array}{l}0.04 \\
0.00\end{array}$ & $\begin{array}{l}0.05 \\
0.00\end{array}$ & $\begin{array}{l}0.06 \\
0.00\end{array}$ & $\begin{array}{l}0.06 \\
0.00\end{array}$ \\
\hline $\begin{array}{l}\text { Number of } \\
\text { observations }\end{array}$ & 713 & 713 & 713 & 692 & 591 & 572 \\
\hline $\mathrm{P}(\mathrm{F})$ & 0.00 & 0.00 & 0.00 & 0.00 & 0.00 & 0.00 \\
\hline
\end{tabular}

Note: underwriter frequency is the number of issues in which a given underwriter took the lead position. Underwriter reputation is the updated Carter-Menaster reputation measure (0-9). Ln(employees) is the number of employees in the IPO company at the time of filing. Ln(offer size) is the value, in current dollars, of the IPO. Offering price is the price at which the IPO shares are sold. Net income/offer amount, is the net income, as stated in the issuing company's financial statement of the last fiscal year, normalized by the value of the issue. Trend is the number of days elapsed since February 9, 1998. $\mathrm{P}$-values of t-statistics are entered beneath coefficient estimates. 
Table 5. Factors Associated with German IPO Underpricing, 1882-1892

\begin{tabular}{lllll}
\hline & 1 & 2 & 3 & 4 \\
\hline Underwriter frequency & 0.64 & 0.41 & & \\
& 0.00 & 0.00 & & 1.87 \\
Underwriter & & & 3.01 & 0.00 \\
reputation & & 0.00 & 6.16 \\
Ln (offer size) & & 0.64 & 0.00 \\
& 0.00 & & 0.01 \\
Offering price per share & 0.01 & 0.01 & 0.01 & 0.06 \\
& 0.04 & 0.06 & 0.04 & 2.28 \\
Trend & 1.76 & 2.46 & 1.49 & 0.00 \\
& 0.02 & 0.00 & 0.05 & 331 \\
Number of observations & 331 & 331 & 331 & 0.00 \\
P(F) & 0.00 & 0.00 & 0.00 & . \\
\hline
\end{tabular}

Note: underwriter frequency is the number of issues in which a given underwriter took the lead position. Underwriter reputation takes the values 0-7 and is based on qualitative factors from the historical literature. Ln(offer size) is the value, in current marks, of the issue. Offering price is the price at which the new shares are sold. Trend is the number of years elapsed since 1881. Data come from the report of the Börsen-Enquette-Kommission (Stock Market Enquiry Commission, 1893). P-values of t-statistics are entered beneath coefficient estimates. 
Figure 1. Market-Adjusted Initial Returns on New Issues:

New York, 1998-2000

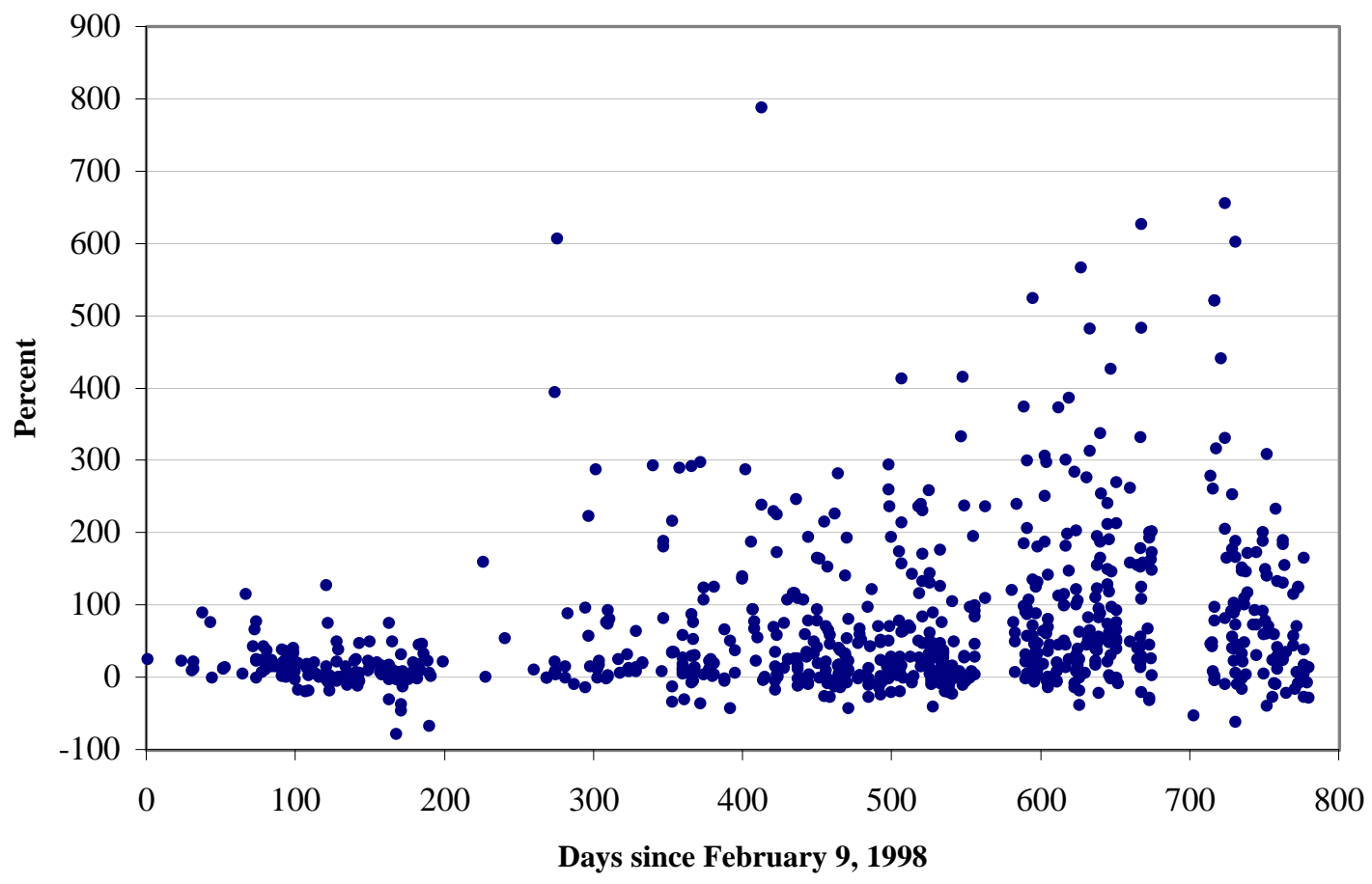


Figure 2. Market-Adjusted Initial Returns on New Issues:

New York, 1998-2000

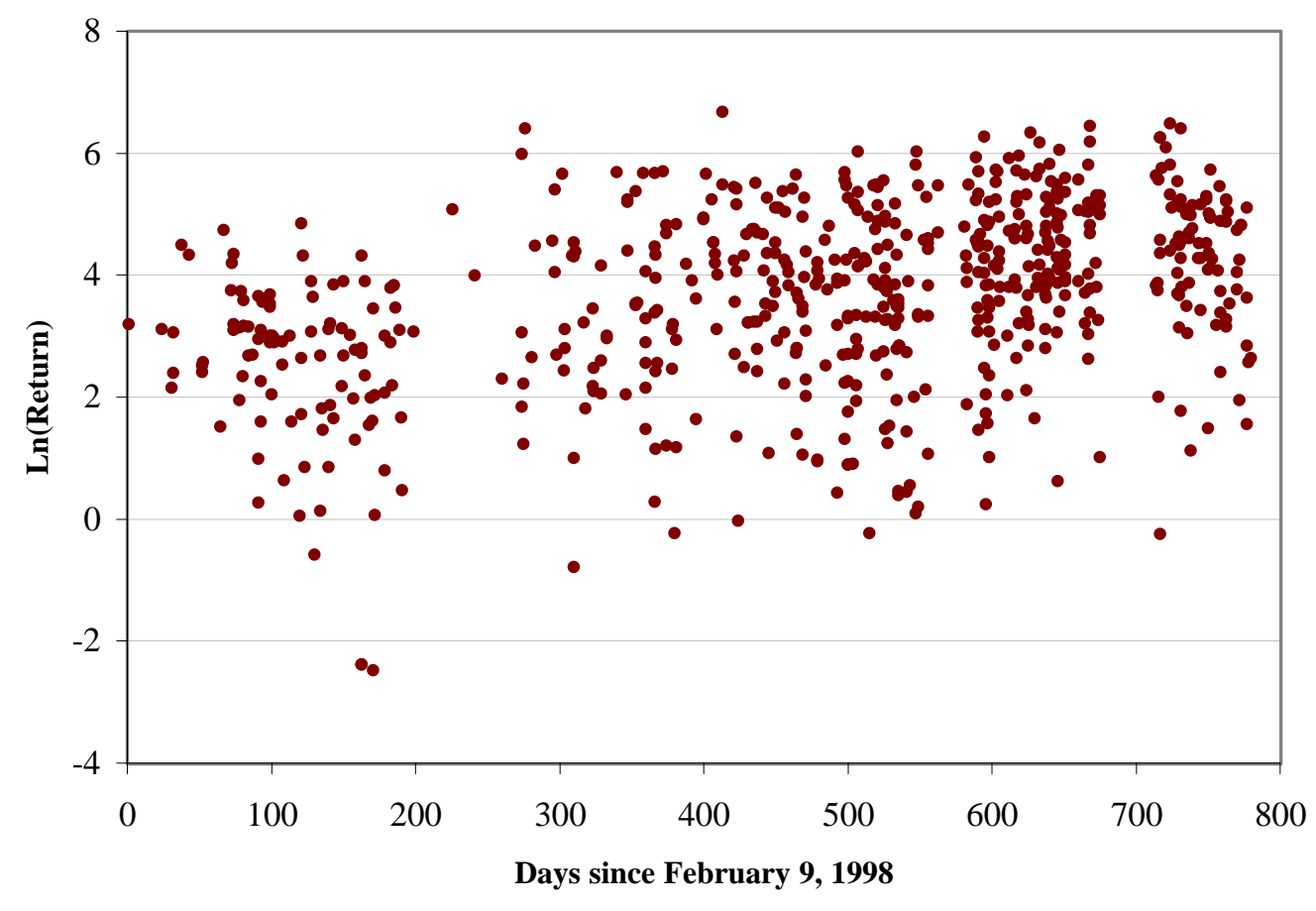


Figure 3. Initial Return on New Issues: Berlin, 1882-1892

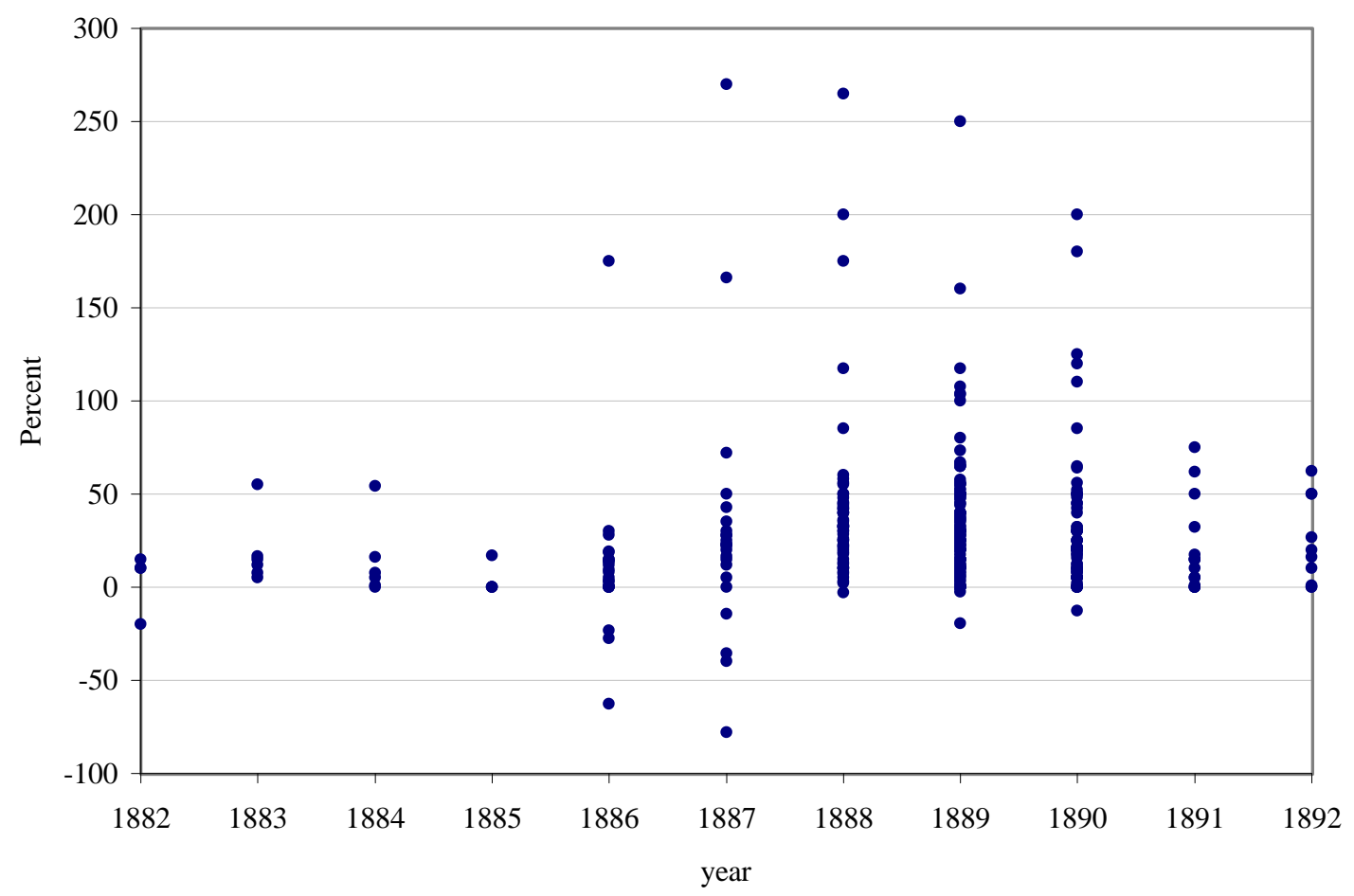


Figure 4. Initial Return on New Issues: Berlin, 1882-1892

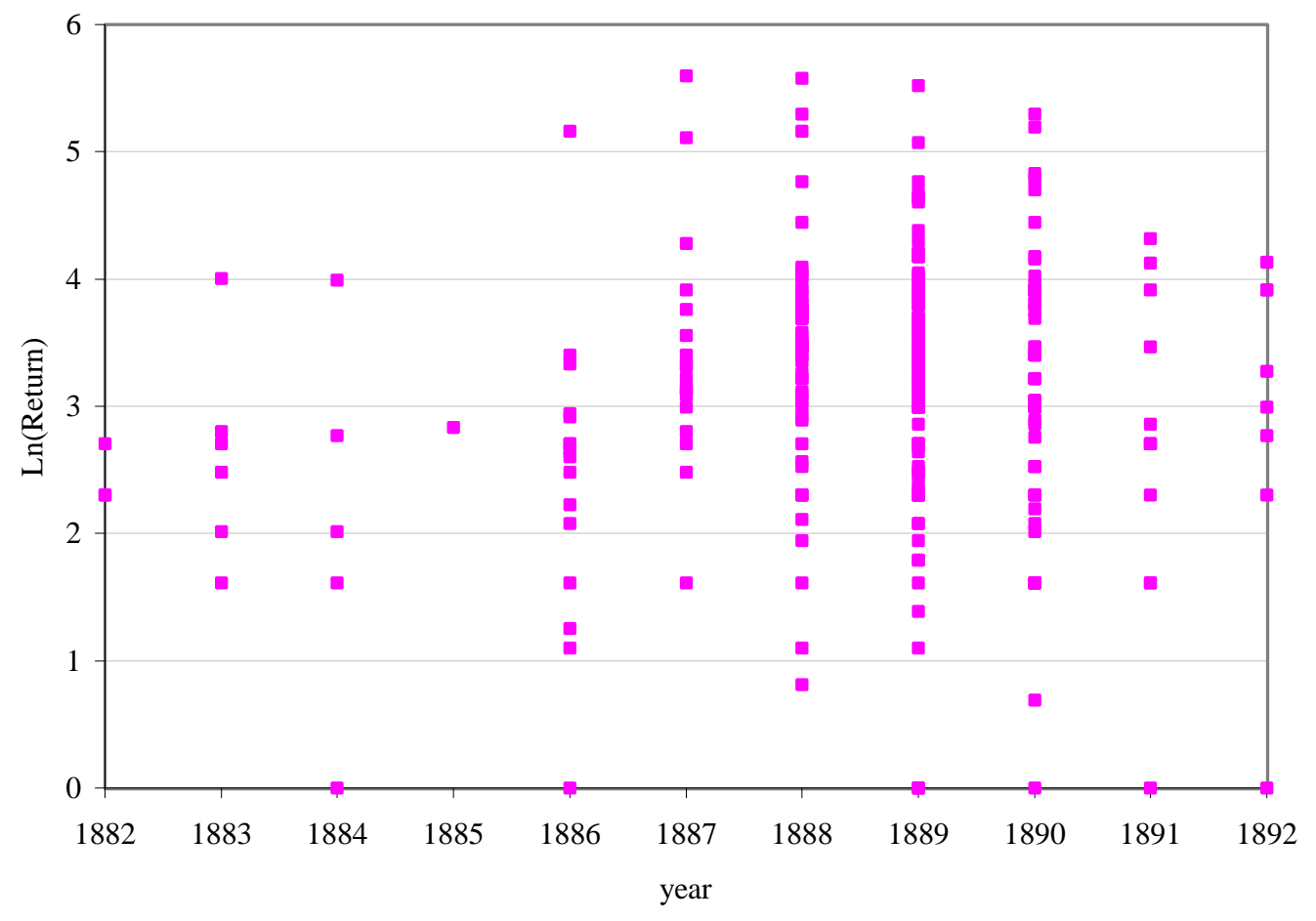


Figure 5. Initial Returns to New Issues: New York, 1998-2000

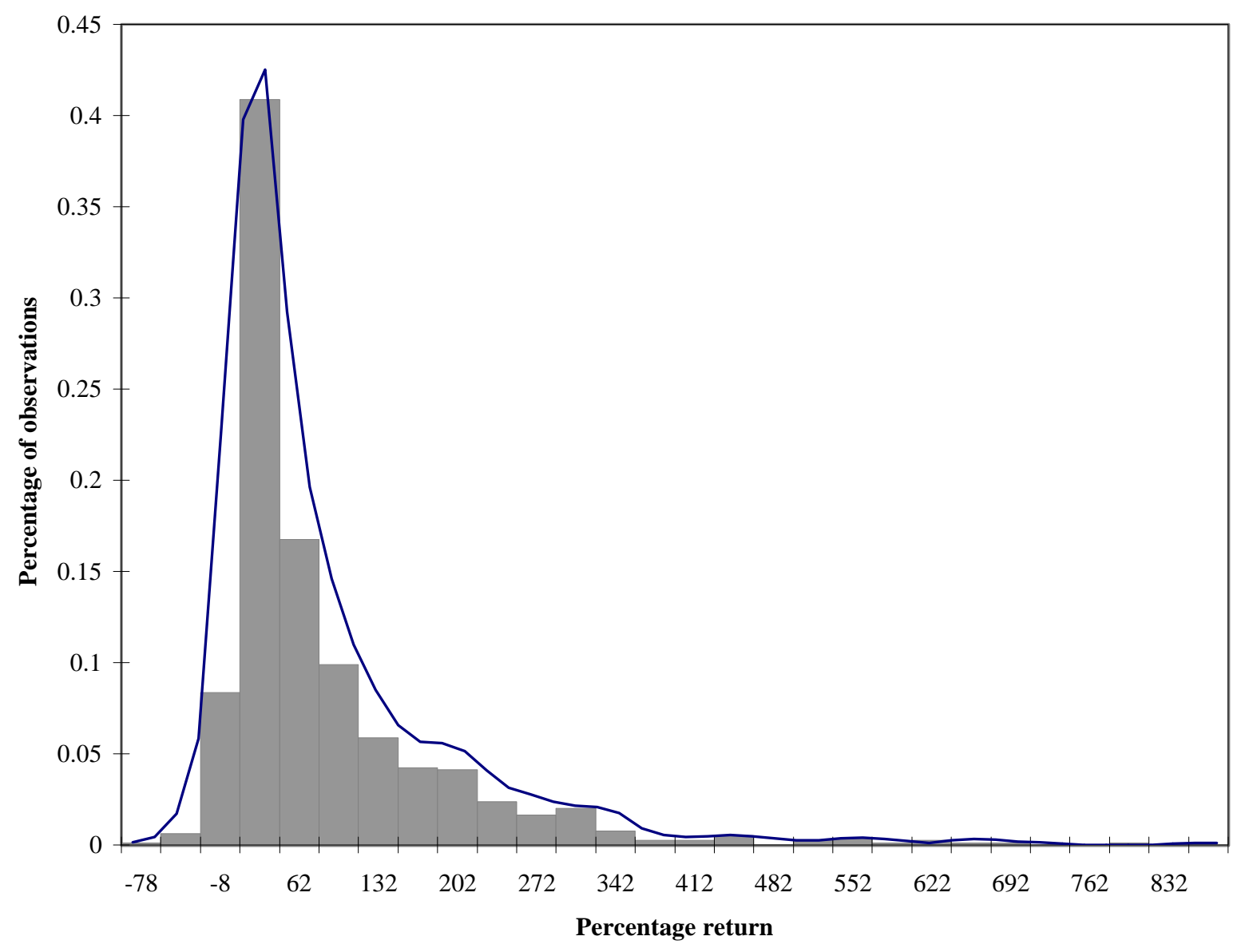


Figure 6. Initial Returns to New Issues: Berlin, 1882-92

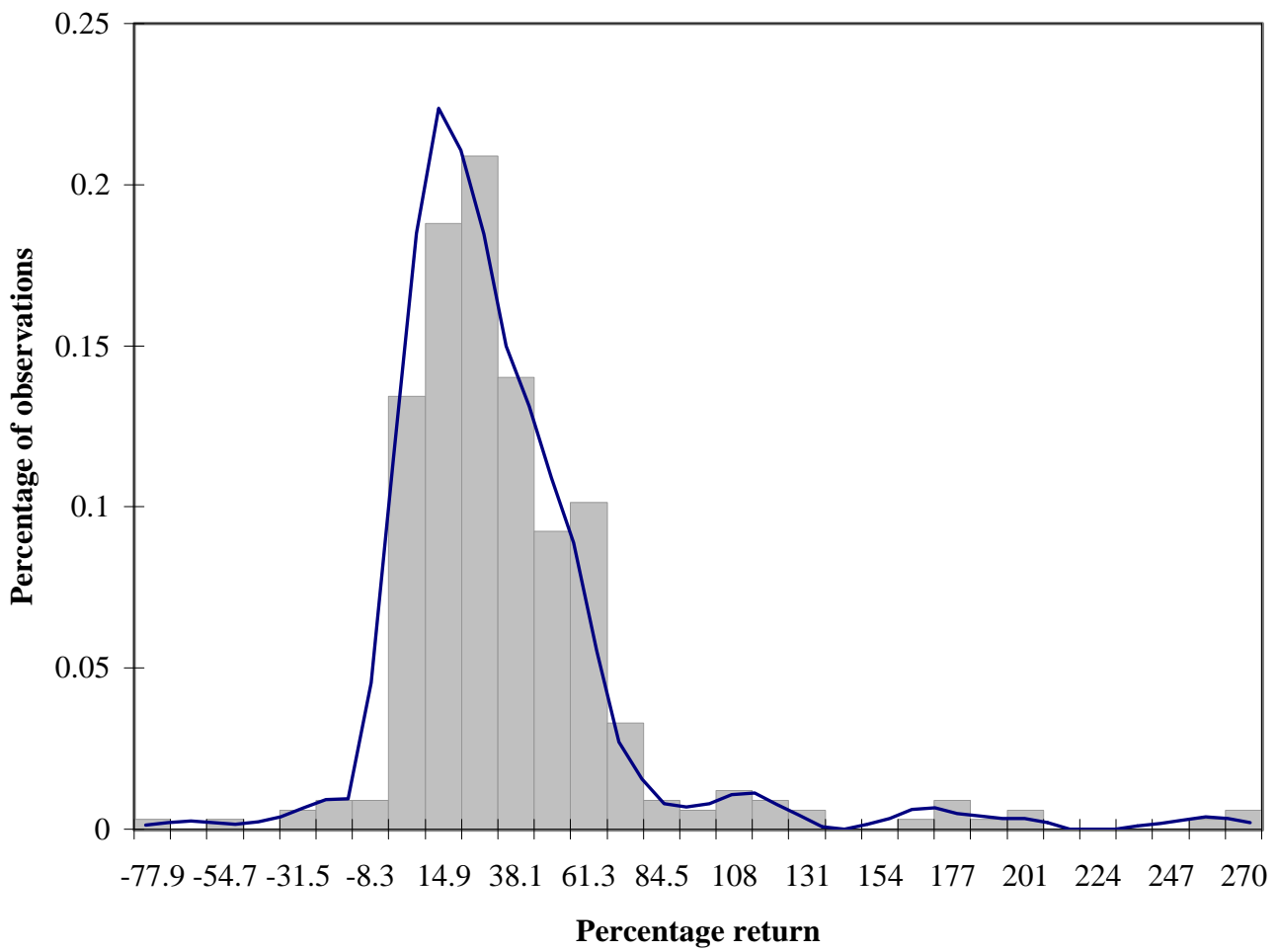


Figure 7. Initial Returns to New Issues:

New York, 1998-2000 and Berlin, 1882-92

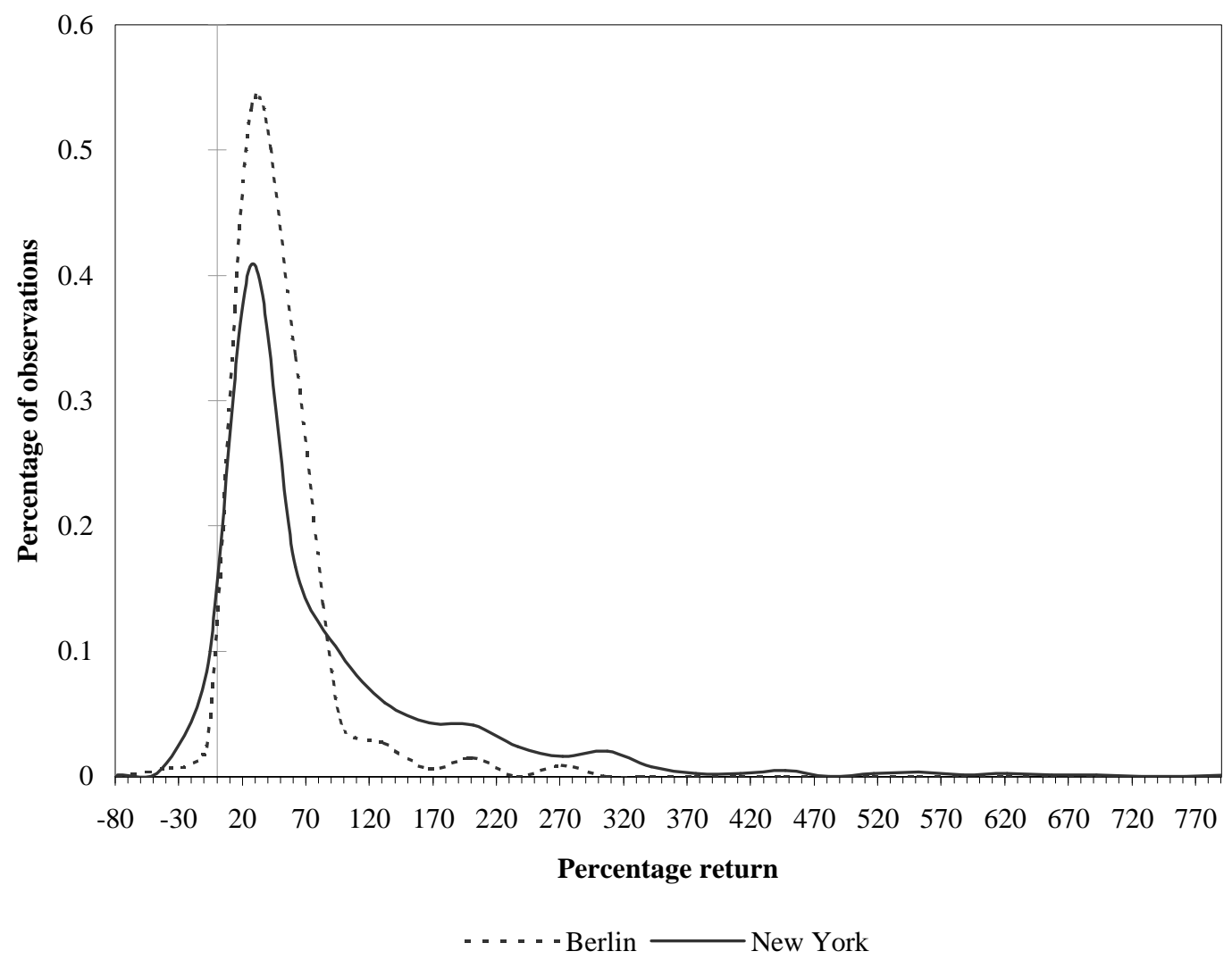


Table A1. Selection Bias Resulting from Price Data Availability

\begin{tabular}{|c|c|c|c|c|c|c|c|c|c|c|c|}
\hline \multirow[t]{2}{*}{ Variable } & \multicolumn{5}{|c|}{ Issues with available day-one market prices } & \multicolumn{5}{|c|}{ Issues with no available day-one market prices } & \multirow{2}{*}{$\begin{array}{r}\text { P-value } \\
\text { (t-stat) }\end{array}$} \\
\hline & Obs & Mean & Std. Dev. & Min & $\operatorname{Max}$ & Obs & Mean & Std. Dev. & Min & $\operatorname{Max}$ & \\
\hline Number of employees & 722 & 799.83 & $3,976.66$ & 0.00 & $82,400.00$ & 177 & 426.81 & $1,488.27$ & 1.00 & $16,000.00$ & 0.11 \\
\hline $\begin{array}{l}\text { Total amount of issue } \\
\text { (millions of dollars) }\end{array}$ & 800 & 190.00 & 744.00 & 1.20 & $16,500.00$ & 218 & 134.00 & 455.00 & 0.99 & $3,450.00$ & 0.15 \\
\hline Offer price (dollars) & 800 & 15.01 & 7.00 & 4.13 & 97.00 & 218 & 12.88 & 11.43 & 5.00 & 158.24 & 0.00 \\
\hline Revenues (millions of dollars) & 766 & 263.00 & $1,670.00$ & 0.00 & $31,400.00$ & 187 & 281.00 & $2,210.00$ & 0.00 & $26,200.00$ & 0.45 \\
\hline Net income (millions of dollars) & 770 & 1.74 & 102.00 & -564.00 & $1,740.00$ & 189 & 19.30 & 217.00 & -118.00 & $2,800.00$ & 0.05 \\
\hline Revenues/amount of issue & 766 & 0.95 & 2.22 & 0.00 & 28.48 & 187 & 1.15 & 2.49 & 0.00 & 28.40 & 0.14 \\
\hline Net income/amount of issue & 770 & -0.06 & 0.22 & -1.47 & 0.71 & 189 & -0.02 & 0.45 & -1.76 & 5.17 & 0.03 \\
\hline Lead underwriter's market share & 800 & 0.04 & 0.03 & 0.00 & 0.09 & 218 & 0.02 & 0.03 & 0.00 & 0.09 & 0.00 \\
\hline $\begin{array}{l}\text { Carter-Menaster reputation } \\
\text { measure (scale 0-9) }\end{array}$ & 664 & 8.44 & 1.19 & 0.00 & 9.00 & 115 & 8.08 & 1.66 & 0.00 & 9.00 & 0.00 \\
\hline $\begin{array}{l}\text { Underwriting cost } \\
\text { (percent of issue amount) }\end{array}$ & 419 & 3.09 & 6.46 & 0.02 & 89.18 & 116 & 4.38 & 5.40 & -25.70 & 25.74 & 0.02 \\
\hline $\begin{array}{l}\text { Elapsed date (thousands of days } \\
\text { since January } 1,1960 \text { ) }\end{array}$ & 799 & 14.40 & 0.21 & 13.92 & 14.71 & 143 & 14.41 & 0.24 & 13.94 & 14.71 & 0.24 \\
\hline
\end{tabular}

Note: Obs. refers to the number of observations available for each variable within each sub-sample. Revenues and net income come from the last fiscal year closing date for each firm. Lead underwriter's market share is determined by frequency as lead underwriter (the number of positions as lead underwriter in the current sample of 1522 issues divided by 1522). Underwriting cost is total reported estimated underwriting costs. The final column, P-value of t-stat., gives the results of a one-sided t-test that the larger mean is larger than the smaller. 
Table A2. Sectoral Distribution of New Issues in the U.S., 1998-2000

\begin{tabular}{|c|c|c|c|c|}
\hline \multirow[t]{2}{*}{ Sector } & \multicolumn{2}{|c|}{ Issues with available price data } & \multicolumn{2}{|c|}{ Issues without available price data } \\
\hline & Frequency & Percent & Frequency & Percent \\
\hline Agriculture & 10 & 1.25 & 7 & 3.21 \\
\hline Apparel & 4 & 0.50 & 2 & 0.92 \\
\hline Bank & 1 & 0.12 & & \\
\hline Biotech & 15 & 1.88 & 7 & 3.21 \\
\hline Brokerage Services & 7 & 0.88 & 2 & 0.92 \\
\hline Business Services & 44 & 5.50 & 12 & 5.50 \\
\hline Chemicals & 4 & 0.50 & & \\
\hline Computer Hardware & 7 & 0.88 & & \\
\hline Computer Software & 54 & 6.75 & 7 & 3.21 \\
\hline Computers & 2 & 0.25 & & \\
\hline Construction Services & 6 & 0.75 & 3 & 1.38 \\
\hline Consumer Products & 5 & 0.62 & 4 & 1.83 \\
\hline Diversified Services & 2 & 0.25 & & \\
\hline Education & 5 & 0.62 & & \\
\hline Electronics & 9 & 1.12 & 8 & 3.67 \\
\hline Energy & 7 & 0.88 & 5 & 2.29 \\
\hline Financial Services & 62 & 7.75 & 38 & 17.43 \\
\hline Health Products & 1 & 0.12 & 2 & 0.92 \\
\hline Healthcare & 7 & 0.88 & 4 & 1.83 \\
\hline Information Technology & 1 & 0.12 & & \\
\hline Insurance & 11 & 1.38 & 3 & 1.38 \\
\hline Interactive Voice & 1 & 0.12 & & \\
\hline Internet Infrastructure & 1 & 0.12 & 1 & 0.46 \\
\hline Internet Services & 233 & 29.12 & 34 & 15.60 \\
\hline Internet Software & 75 & 9.38 & 10 & 4.59 \\
\hline Leisure & 4 & 0.50 & 3 & 1.38 \\
\hline Machinery & 7 & 0.88 & 3 & 1.38 \\
\hline Media & 23 & 2.88 & 3 & 1.38 \\
\hline Oil \& Gas & 7 & 0.88 & & \\
\hline Packaging & 4 & 0.50 & & \\
\hline Pharmaceuticals & 11 & 1.38 & 2 & 0.92 \\
\hline Real Estate & 5 & 0.62 & 4 & 1.83 \\
\hline Retail & 25 & 3.12 & 8 & 3.67 \\
\hline Semiconductor & 2 & 0.25 & & \\
\hline Telecom Equipment & 3 & 0.38 & & \\
\hline Telecommunications & 107 & 13.38 & 17 & 7.80 \\
\hline Telecommunications Service & 2 & 0.25 & & \\
\hline Transportation & 8 & 1.00 & 1 & 0.46 \\
\hline Travel Services & 2 & 0.25 & 1 & 0.46 \\
\hline Waste Management & 3 & 0.38 & 1 & 0.46 \\
\hline Sector name missing & 13 & 1.62 & 26 & 11.93 \\
\hline Total & 800 & 100 & 218 & 100 \\
\hline
\end{tabular}


Table A3. Selection Bias Resulting from Price Data Availability

\begin{tabular}{|c|c|c|c|c|c|c|c|c|c|c|c|}
\hline \multirow[t]{2}{*}{ Variable } & \multicolumn{5}{|c|}{ Tssues with available day-one market prices } & \multicolumn{5}{|c|}{ Issues with no available day-one market prices } & \multirow{2}{*}{$\begin{array}{r}\text { P-value } \\
\text { (t-stat) }\end{array}$} \\
\hline & Obs & Mean & Std. Dev. & Min & Max & Obs & Mean & Std. Dev. & Min & $\operatorname{Max}$ & \\
\hline $\begin{array}{l}\text { Total amount of issue } \\
\text { (millions of marks) }\end{array}$ & 335 & 3.13 & 6.66 & 0.10 & 100.00 & 107 & 2.78 & 7.30 & 0.06 & 63.00 & 0.32 \\
\hline Offer price (marks) & 333 & 993.54 & 304.18 & 100.00 & 3000.00 & 104 & 875.00 & 515.16 & 100.00 & 3000.00 & 0.00 \\
\hline Kurs (at unofficial listing date) & 178 & 140.08 & 40.88 & 40.50 & 370.50 & 36 & 120.51 & 58.61 & 40.00 & 340.00 & 0.0 \\
\hline Kurs (at official listing date) & 262 & 148.66 & 55.57 & 62.50 & 409.00 & 54 & 130.56 & 56.00 & 60.60 & 385.00 & $0 .($ \\
\hline Kurs on December 31, 1890 & 256 & 129.04 & 46.80 & 6.25 & 363.50 & 47 & 122.43 & 55.61 & 68.50 & 380.00 & 0.19 \\
\hline Kurs on December 31, 1892 & 267 & 109.89 & 46.29 & 17.75 & 302.00 & 60 & 106.21 & 57.55 & 12.25 & 330.00 & 0.3 \\
\hline Lead underwriter frequency & 333 & 10.75 & 9.57 & 1.00 & 34.00 & 108 & 9.73 & 10.11 & 1.00 & 34.00 & 0.17 \\
\hline Lead underwriter reputation (0-7) & 333 & 4.14 & 2.06 & 0.00 & 7.00 & 108 & 3.57 & 2.31 & 0.00 & 7.00 & 0.01 \\
\hline Year of issue & 335 & 1888.54 & 1.83 & 1882.00 & 1892.00 & 108 & 1888.51 & 2.65 & 1882.00 & 1892.00 & 0.4 \\
\hline
\end{tabular}

Note: Obs. Refers to the number of observations available for each variable within each sub-sample. Kurs is the price of a share scaled by its issue price (times 100 ). Lead underwriter frequency is the number of times the underwriting took the lead position in the overall sample. The final column, P-value of t-stat., gives the results of a one-sided t-test that the larger mean is larger than the smaller. 
Table A4. Sectoral Distribution of New Issues in Berlin, 1882-1892

\begin{tabular}{lrrrr}
\hline Sector & \multicolumn{2}{c}{$\begin{array}{c}\text { Issues with available price data } \\
\text { Frequency }\end{array}$} & \multicolumn{2}{c}{$\begin{array}{r}\text { Issues without available price data } \\
\text { Percent }\end{array}$} \\
\hline Banks & 46 & 13.73 & 14 & 12.84 \\
Construction & 15 & 4.48 & 9 & 8.26 \\
Mining and smelting & 72 & 21.49 & 28 & 25.69 \\
Brewing & 30 & 8.96 & 7 & 6.42 \\
Machinery and railroad provisions & 38 & 11.34 & 18 & 16.51 \\
Textiles & 16 & 4.78 & 5 & 4.59 \\
Miscellaneous & 118 & 35.22 & 28 & 25.69 \\
& & & 109 & 100 \\
Total & 335 & 100 & & \\
\hline
\end{tabular}

